\title{
Sant'Imbenia (Alghero): further archaeometric evidence for an Iron Age market square
}

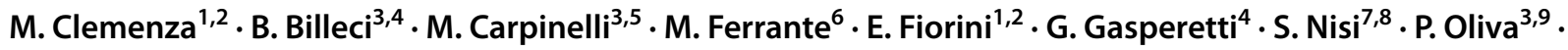 \\ V. Sipala ${ }^{3,5} \cdot$ P. R. Trincherini ${ }^{8} \cdot$ I. M. Villa ${ }^{1,10,11} \cdot$ M. Rendeli $^{3,5}$ (D)
}

Received: 12 January 2021 / Accepted: 5 August 2021 / Published online: 5 October 2021

(c) The Author(s) 2021, corrected publication 2021

\begin{abstract}
Lead isotope compositions were determined for 18 metal objects from the archaeological site of Sant'Imbenia, NW Sardinia, dating to the end of the ninth century BCE onwards. The provenance of some objects is unambiguously traced to SW Sardinia; other objects could derive either from central Sardinia or the Iberian coastal ranges. The variety of the provenances attests to a wide trade network that spanned the entire island of Sardinia and extended to the Iberian sites.
\end{abstract}

Keywords Iron Age Sardinia $\cdot$ Sant'Imbenia $\cdot$ Alghero $\cdot$ Lead isotope analysis $\cdot$ Provenances

\section{Introduction}

The archaeological site of Sant' Imbenia in NW Sardinia (lat. $40^{\circ} 37^{\prime} 21.48^{\prime \prime} \mathrm{N}$; long. $\left.8^{\circ} 11^{\prime} 47.74^{\prime \prime} \mathrm{E}\right)^{1}$ lies in a sheltered natural harbour that has been called Porto Conte since the Middle Ages. It is located $10 \mathrm{~km}$ to the WNW of Alghero and at present is a marshy and sandy shallow coastal area, protected from the prevailing wind (Mistral). About $100 \mathrm{~m}$ inland of the present-day coastline, a nuraghe was built during the fourteenth century BCE, surrounded by a small number of huts. The nuraghe was a single-tower building that

\footnotetext{
1 The coordinates were taken by Google Earth on the top of the nuraghe.
}

\section{Rendeli}

rendeli@uniss.it

1 Dipartimento di Fisica G. Occhialini, Università degli Studi di Milano Bicocca, Piazza della Scienza 3, 20126 Milano, Italy

2 Istituto Nazionale di Fisica Nucleare-Sez. Milano Bicocca, Piazza della Scienza 3, 20126 Milano, Italy

3 Università degli Studi di Sassari, Piazza Università 21, 07100 Sassari, Italy

4 Ministero della Cultura-Soprintendenza Archeologia, Belle Arti e Paesaggio per le province di Sassari e Nuoro, Piazza Sant'Agostino 2, 07100 Sassari, Italy

5 Laboratori Nazionali del Sud-Istituto Nazionale di Fisica Nucleare, Via Santa Sofia 62, 95123 Catania, Italy

6 Trace Technologies, Via I. Silone 6, 64015 Nereto, TE, Italy was reinforced and surrounded by a bastion built probably during the construction of the square (Bafico et al 1985; Bafico 1998; Giardino and Lo Schiavo 2007). The nuraghe was in use until the tenth century BCE and was then probably abandoned in a subsequent period, but the village possibly survived, as the society of the whole region (known as Nurra) started to undergo a deep process of transformation.

Recent excavations (De Rosa et al 2017; Rendeli 2018) have unearthed a surprising find: a monumental area, which acted as a market place, created approximately $800 \mathrm{BCE}$ (Fig. 1).

7 Servizio di Chimica, Laboratorio Nazionale del Gran Sasso-Istituto Nazionale di Fisica Nucleare, Via G. Acitelli 22, 67100 Assergi, AQ, Italy

8 LIMS, Laboratorio Nazionale del Gran Sasso-Istituto Nazionale di Fisica Nucleare, Via G. Acitelli 22, 67100 Assergi, AQ, Italy

9 Istituto Nazionale di Fisica Nucleare-Sez. di Cagliari Monserrato, Strada provinciale per Sestu, Km 1, 09042 Monserrato, CA, Italy

10 Centro Universitario Datazioni e Archeometria Milano, Università degli Studi di Milano Bicocca, Piazza della Scienza 1, 20126 Milano, Italy

11 Institut für Geologie, Universität Bern, Baltzerstrasse 3, 3012 Bern, Switzerland 


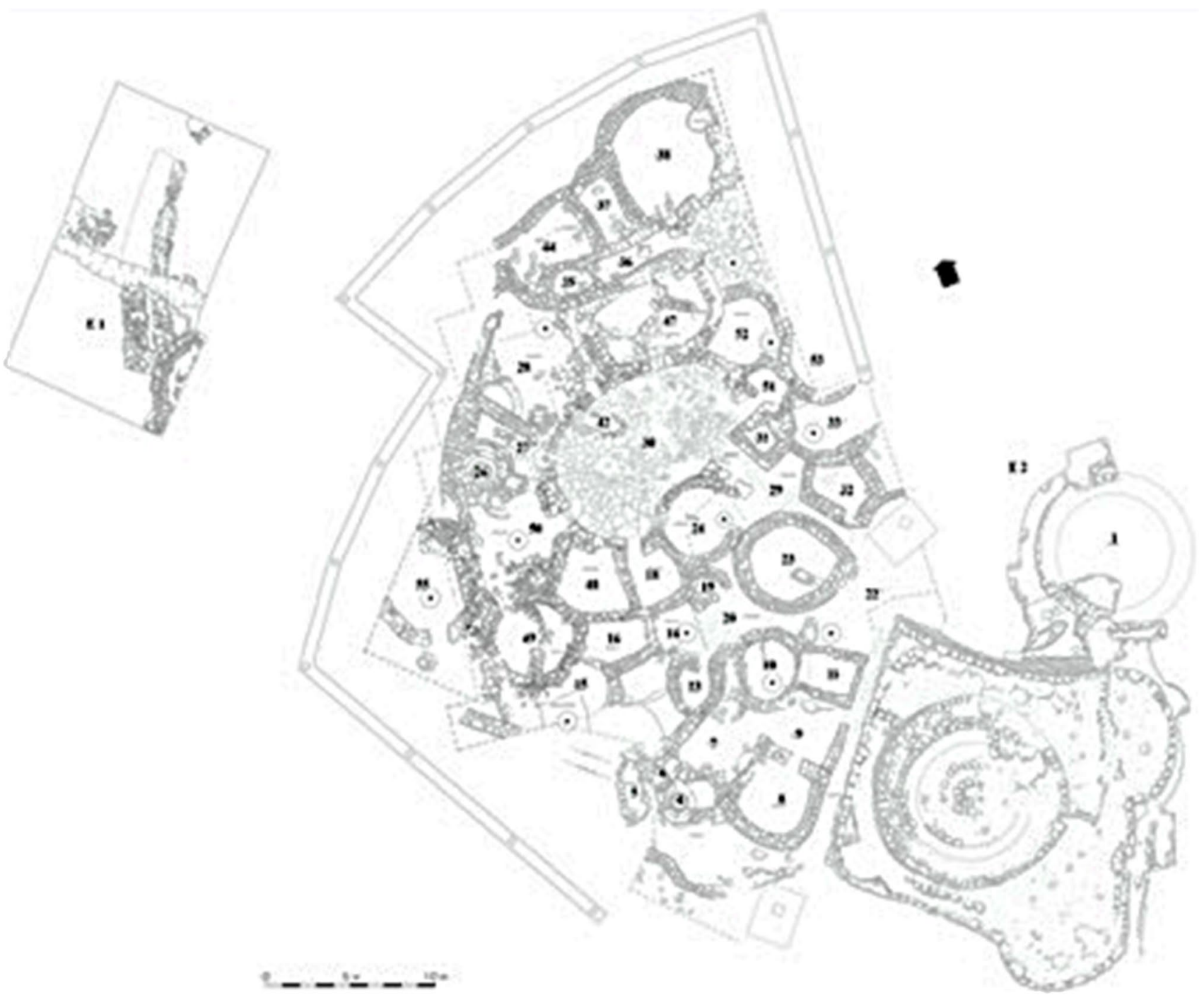

Fig. 1 Plan of the Sant'Imbenia Nuragic complex (Alghero, Sardinia)

Such a market at this early date points to seafaring travel around the Western Mediterranean Sea at the time of settlement by Aegean and Levantine seafarers (Rendeli 2018). The geographical position of Sant'Imbenia makes it a favourable stop on the sea routes in the Western Mediterranean. Marine currents lead westward from NW Sardinia, making it a doorway to the Balearic Islands and S Iberia; moreover, the sheltered natural gulf of Porto Conte lies near the Nurra area, one of the richest areas of Sardinia both for agriculture and sheep breeding and for metals. The floor of the market place was higher than the shops and open areas, and around it one may imagine the presence of shops (A 52, 51, 24, 18, 48); working spaces (A 50,28 ); and a bigger room (A 47) in which it is possible to recognize a sort of institutional hall where economic exchanges and treaties could have been stipulated.
Great importance has been given to the "shops". In many of them, some repositories or hoards were found under the floor: two from A 24 that, together with the two found in the nearby A 26, capanna dei ripostigli, amount to more than $140 \mathrm{~kg}$ of metal, mainly copper, but also some bronze objects (axes, part of a sword, bracelets).

Among other metal objects, there are many pieces of lead: not slag or ingots but rather clamps for mending pottery known as laminae. These were found all over the area of excavation in the levelling layers or in the preparations of floors (Depalmas et al. 2011: 231-256). Some of these were found whole; some were fragmented.

In A 48 another repository contained more than $1 \mathrm{~kg}$ of milk thistle (Silybum marianum) seeds: this is an extraordinary discovery because the seeds were valued as much as precious metals. Pliny the Elder regarding this kind of seed 
states that the origin of this wild plant can be identified in the Levantine area: the main reason could have been medical use, for the treatment gastric or liver problems which may have affected sailors arriving in the Gulf of Porto Conte (Marino 2014).

As regards the secondary products, of great importance is the collection of more than 200 sherds of amphorae rims, mainly produced at Sant'Imbenia and exported to the Italian peninsula, to N Africa (Utica and Cartage), and S Spain (Huelva, Cadiz, Malaga, La Rebanadilla, Castillo de Doña Blanca) with the Sardinian wine drinking set composed of askoid jugs, neck vases, and possibly cups.

This rich environment was exploited by local societies, which created a network and traded with merchants coming from the Levantine and Aegean areas, from the Italian peninsula, N Africa and S Spain (De Rosa et al 2018; Rendeli 2018).

These conditions likely spurred growing interest in this region among foreign merchants; together with the endogenic transformations occurring in local societies, this caused a critical change in the political organization and in social and economic life. In this phase, craft specializations were developed for the exploitation of both primary and secondary resources. The beginning of the relationship was based on the demandoffer scheme in many fields of local production: primarily as cereals, wine, oil, cheese, meat, metals, leather; secondarily for all the derived products or those useful to increase the exchange: potters, craftsmen, blacksmiths (Giardino and Lo Schiavo 2007; De Rosa et al 2017; Rendeli 2018). These transformations changed the local society, which became specialized and segmented: many of these changes were carried out within the local society, others with the collaboration and co-sharing of foreign specialists and people.

The present investigation endeavours to ascertain the range of commercial traffic during the heyday of the Sant'Imbenia emporium. A very useful tool is the use of lead isotope compositions ( $\mathrm{PbIC}$ ) to infer the provenance area of metal artefacts (Grögler et al 1966; Gale et al 1997; Trincherini et al 2001, 2009; Villa 2016). Especially the PbIC of circum-Mediterranean ore deposits of antiquity has been documented in a number of studies and databases (Stos Gale et al. 1995: Oxalid database; Trincherini-LIMS (to be published); Atzeni et al 2005; Begemann et al 2001).

\section{Description of samples}

Eighteen metal samples from Sant'Imbenia were selected for $\mathrm{PbIC}$ analyses. The following catalogue briefly reports the nature of each object, its context and possible date based on stratigraphic analysis:

1. A 47, US 832: part of a cubic lead weight from a layer of friable black earth in the NW area of A47 beside the north wall. First half of the eighth century BCE. $1.4 \times 1.5 \mathrm{~cm}$; passing hole diam. $0.2 \mathrm{~cm}$ in upper part; $0.3 \mathrm{~cm}$ in lower part; $11.0 \mathrm{~g}$

2. A 24, US 51: large lead clamp to repair a storage vessel, composed of many laminae: it comes from a layer which obliterates the whole area after the abandonment of the site; it may date to the first half of the sixth century BCE. Big clamp: length $10.0 \mathrm{~cm}$, length $2.0 \mathrm{~cm}$, thickness $0.5 \mathrm{~cm}$ : length to the elbow $5.2 \mathrm{~cm}$; after the elbow $2.4 \mathrm{~cm}$, thickness $0.8 \mathrm{~cm}$, max thickness $1.4 \mathrm{~cm}$; nail height $3.6 \mathrm{~cm}$ thickness $0.8 \mathrm{~cm}$; head height $2.5 \mathrm{~cm}$, length $1.6 \mathrm{~cm}$; weight $122 \mathrm{~g}$. Big lamina: height $5.8 \mathrm{~cm}$, length $1.7 \mathrm{~cm}$, thickness $1.3 \mathrm{~cm}$, weight $32 \mathrm{~g}$. Small lamina: height $3.4 \mathrm{~cm}$, length $1.5 \mathrm{~cm}$, thickness $0.5 \mathrm{~cm}$, max $0.9 \mathrm{~cm}$, weight $20 \mathrm{~g}$. Total weight $174 \mathrm{~g}$

3. A 24, US 404: lead lamina from the floor in which a hole was created to insert the large storage vessel, a repository for copper slag, axes and part of a sword. Dated around the middle eighth century BCE. Height $2.6 \mathrm{~cm}$, length $1.6 \mathrm{~cm}$, thickness $0.5 \mathrm{~cm}$, weight $20 \mathrm{~g}$

4. A 50, US 111: oval lead plaque missing one extremity from a layer beside the vertical kiln in A50 dated to the seventh century BC. Height $7.5 \mathrm{~cm}$; length $5.0 \mathrm{~cm}$; thickness $0.3 \mathrm{~cm}$; hole height $0.7 \mathrm{~cm}$, length $0.4 \mathrm{~cm}$, weight $77 \mathrm{~g}$

5. A 18, US 434: lead lamina, part of a clamp coming from the preparation layer of a floor; second quarter of the eighth century BCE. Height $3.7 \mathrm{~cm}$, length $1.1 \mathrm{~cm}$, thickness $0.3 \mathrm{~cm}$, $\max 0.5 \mathrm{~cm}$, weight $10 \mathrm{~g}$

6. A 47, US 52: part of a clamp from a layer of ancient obliteration in A47 after the abandonment of the site, first half of the sixth century $\mathrm{BC}$; height $4.3 \mathrm{~cm}$, length $1.1 \mathrm{~cm}$, thickness $0.2 \mathrm{~cm}$; nail: height $1.4 \mathrm{~cm}$, thickness $0.45 \mathrm{~cm}$; head length $1.4 \mathrm{~cm}$, height $0.8 \mathrm{~cm}$, thickness of the head $0.2 \mathrm{~cm}$, weight $9 \mathrm{~g}$

7. A 48, US 829: lead lamina (?) with a ribbon section coming from the preparation layer of a floor in A48, second quarter of the eighth century BC. Height $3.6 \mathrm{~cm}$, length $1.4 \mathrm{~cm}$, thickness $0.5 \mathrm{~cm}$, weight $11 \mathrm{~g}$

8. A 48, US 396: cubic lead weight from a layer of fill of a large fossa in the most recent floor of A48, near the rim of the large storage vessel used as repository for milk whistle seeds; mid eighth century BCE. $1.9 \times 1.8 \times 1.5$ $\mathrm{cm}^{3}$, weight $47 \mathrm{~g}$

9. A 52, US 675: part of lead lamina from the preparation layer of a floor US 505; end of the eighth-first half of the seventh century BCE. Height $2.7 \mathrm{~cm}$, length $1.2 \mathrm{~cm}$, thickness $0.6 \mathrm{~cm}$, weight $10 \mathrm{~g}$

10. A 49, US 1100: big lead clamp created to restore at least 6 sherds of a large storage vessel, from a floor layer of A49: dated to between the eighth and seventh centuries BCE. Length $1.4 \mathrm{~cm}$, thickness $0.4 \mathrm{~cm}$; weight with the sherds of pottery $448 \mathrm{~g}$ 
Table 1 List showing analysed samples, objects, measured isotope ratios and analytical technique used

\begin{tabular}{|c|c|c|c|c|c|c|c|c|c|}
\hline No & Sample & Artefact & ${ }^{207} \mathrm{~Pb} /{ }^{206} \mathrm{~Pb}$ & $\begin{array}{l}\text { uncertainty } \\
\pm 2 \sigma\end{array}$ & ${ }^{208} \mathrm{~Pb} /{ }^{206} \mathrm{~Pb}$ & $\begin{array}{l}\text { uncertainty } \\
\pm 2 \sigma\end{array}$ & ${ }^{206} \mathrm{~Pb} /{ }^{204} \mathrm{~Pb}$ & $\begin{array}{l}\text { uncertainty } \\
\pm 2 \sigma\end{array}$ & Instrument \\
\hline 1 & SI_2013_A47_U832 & Cubic weight & 0.87397 & 0.00003 & 2.1223 & 0.00011 & 17.903 & 0.002 & MC-ICP-MS \\
\hline 2 & SI_2010_A24_US51 & Agraffe & 0.87390 & 0.00003 & 2.1223 & 0.00012 & 17.902 & 0.002 & MC-ICP-MS \\
\hline 3 & A24 US404 & Lamina & 0.87336 & 0.00004 & 2.1183 & 0.00014 & 17.863 & 0.007 & TIMS \\
\hline 4 & A50 US111 & Plaque & 0.87230 & 0.00006 & 2.1175 & 0.00017 & 17.898 & 0.007 & TIMS \\
\hline 5 & SI_2012_A18_US434 & Lamina & 0.87222 & 0.00004 & 2.1203 & 0.00013 & 17.937 & 0.002 & MC-ICP-MS \\
\hline 6 & SI_2009_A47_US52 & Clamp & 0.86036 & 0.00002 & 2.1069 & 0.00008 & 18.203 & 0.002 & MC-ICP-MS \\
\hline 7 & SI_2013_A48_US829 & Lamina (?) & 0.86014 & 0.00003 & 2.1067 & 0.00011 & 18.208 & 0.002 & MC-ICP-MS \\
\hline 8 & A48 US396 & Cubic weight & 0.86007 & 0.00003 & 2,1064 & $0,00,017$ & 18.207 & 0.002 & MC-ICP-MS \\
\hline 8bis & A48 US396 & Cubic weight ext & 0.85999 & 0.00002 & 2.1060 & 0.00007 & 18.204 & 0.002 & MC-ICP-MS \\
\hline 9 & A52 US675 & Lamina & 0.85815 & 0.00005 & 2.1028 & 0.00012 & 18.197 & 0.007 & TIMS \\
\hline 10 & A49 US1100 & Clamp & 0.85785 & 0.00005 & 2.1052 & 0.00019 & 18.278 & 0.007 & TIMS \\
\hline 11 & A44 US798 & Lamina & 0.85741 & 0.00005 & 2.1007 & 0.00008 & 18.193 & 0.004 & TIMS \\
\hline 12 & A52 US505 & Lamina & 0.85580 & 0.00005 & 2.1028 & 0.00013 & 18.261 & 0.007 & TIMS \\
\hline 13 & A47 US135 & Lamina & 0.85529 & 0.00005 & 2.0921 & 0.00010 & 18.307 & 0.007 & TIMS \\
\hline 14 & SI_2011_A47_US175 & Object & 0.85455 & 0.00002 & 2,1003 & 0.00010 & 18.332 & 0.002 & MC-ICP-MS \\
\hline 15 & SI_2013_A16_US923 & Lamina & 0.85448 & 0.00003 & 2.1003 & 0.00015 & 18.322 & 0.002 & MC-ICP-MS \\
\hline 16 & SI_2015_A29_US1372 & Lamina & 0.85448 & 0.00002 & 2.1003 & 0.00011 & 18.335 & 0.002 & MC-ICP-MS \\
\hline 17 & E1 US1246 & Clamp & 0.85383 & 0.00004 & 2.0962 & 0.00012 & 18.298 & 0.007 & TIMS \\
\hline 18 & SI_2008_US1_SO & Clamp & 0.83942 & 0.00004 & 2.0834 & 0.00015 & 18.663 & 0.002 & MC-ICP-MS \\
\hline
\end{tabular}

11. A 44, US 798: part of a lead lamina from a fill layer of a cut made in modern times. Height $2.4 \mathrm{~cm}$, length $2.4 \mathrm{~cm}$, thickness $0.4 \mathrm{~cm}$, weight $20 \mathrm{~g}$

12. A 52, US 505: small part of a lead lamina from a floor of A52; end of the eighth-mid seventh centuries BCE. Height $2.3 \mathrm{~cm}$, length $1.0 \mathrm{~cm}$, thickness $0.4 \mathrm{~cm}$, weight $6 \mathrm{~g}$

13. A 47, US 135: lead object with an ovoid profile, from a floor layer in A47; second half of the eighth century BCE. Height $3.7 \mathrm{~cm}$, length $1.8 \mathrm{~cm}$, thickness $1.3 \mathrm{~cm}$, weight $42 \mathrm{~g}$

14. A 47, US 175: lead object from a floor layer in A47, dated to around middle eighth century BCE: height $\max 4.2 \mathrm{~cm}$, length on thicker part $2.4 \mathrm{~cm}$, otherwise $1.9 \mathrm{~cm}$; thickness $0.8-0.4 \mathrm{~cm}$, weight $28 \mathrm{~g}$

15. A16, US 923: lead element possibly decorating a wooden box, from the preparation layer of a floor in A16; dated to between mid eighth and mid sixth centuries BCE. Height 2.8, length $1.1 \mathrm{~cm}$, thickness from $2.4 \mathrm{~cm}$ to $0.4 \mathrm{~cm}$, weight $12 \mathrm{~g}$

16. A 29, US 1372: small lead lamina, part of a clamp, found between the blocks making up the floor of the Piazzetta (A29), dated to between the mid eighth and the mid seventh centuries BCE. Height $1.85 \mathrm{~cm}$, length $0.8 \mathrm{~cm}$, thickness $0.4 \mathrm{~cm}$, weight $3 \mathrm{~g}$

17. S expansion of the area E1, US 1246 lead clamp found in a layer of abandonment of the area during the first half of the sixth century BCE. Height $4.0 \mathrm{~cm}$, length $1.4 \mathrm{~cm}$, height $1.2 \mathrm{~cm}$; thickness of the laminae $0.2 \mathrm{~cm}$, thickness of the nails $0.5 \mathrm{~cm}$, weight $14 \mathrm{~g}$

18. 2008, US 1: SW area, part of a lead clamp from the humus layer in the SW area of the excavation. No date available. Height $4.9 \mathrm{~cm}$, length 0.9 , thickness $0.4 \mathrm{~cm}$, weight $15 \mathrm{~g}$

Lead isotope analyses were performed partly by thermal ionization mass spectrometry (TIMS) by the Laboratori Nazionali del Gran Sasso of the Istituto Nazionale di Fisica Nucleare (LNGS), Assergi, Italy, and partly by multicollector ion-source mass spectrometry (MC-ICPMS) by the Centro Universitario Datazioni e Archeometria (CUDAM), University of Milano Bicocca, Italy. The analytical procedures employed are described in Trincherini et al 1983; 2001 and Villa 2009, respectively.

Results are shown in Table 1.

\section{Geographical provenance}

The PbIC measurements display a great variety, which extends far beyond the PbIC range of the known ore showings in Nurra, the immediate hinterland of the site. 
Fig. 2 Scatter plot of lead isotope compositions $\left({ }^{208} \mathrm{~Pb} /{ }^{206} \mathrm{~Pb}\right.$ vs $\left.{ }^{207} \mathrm{~Pb} /{ }^{206} \mathrm{~Pb}\right)$ of the minerary areas and 18 samples from Sant'Imbenia (red circles)

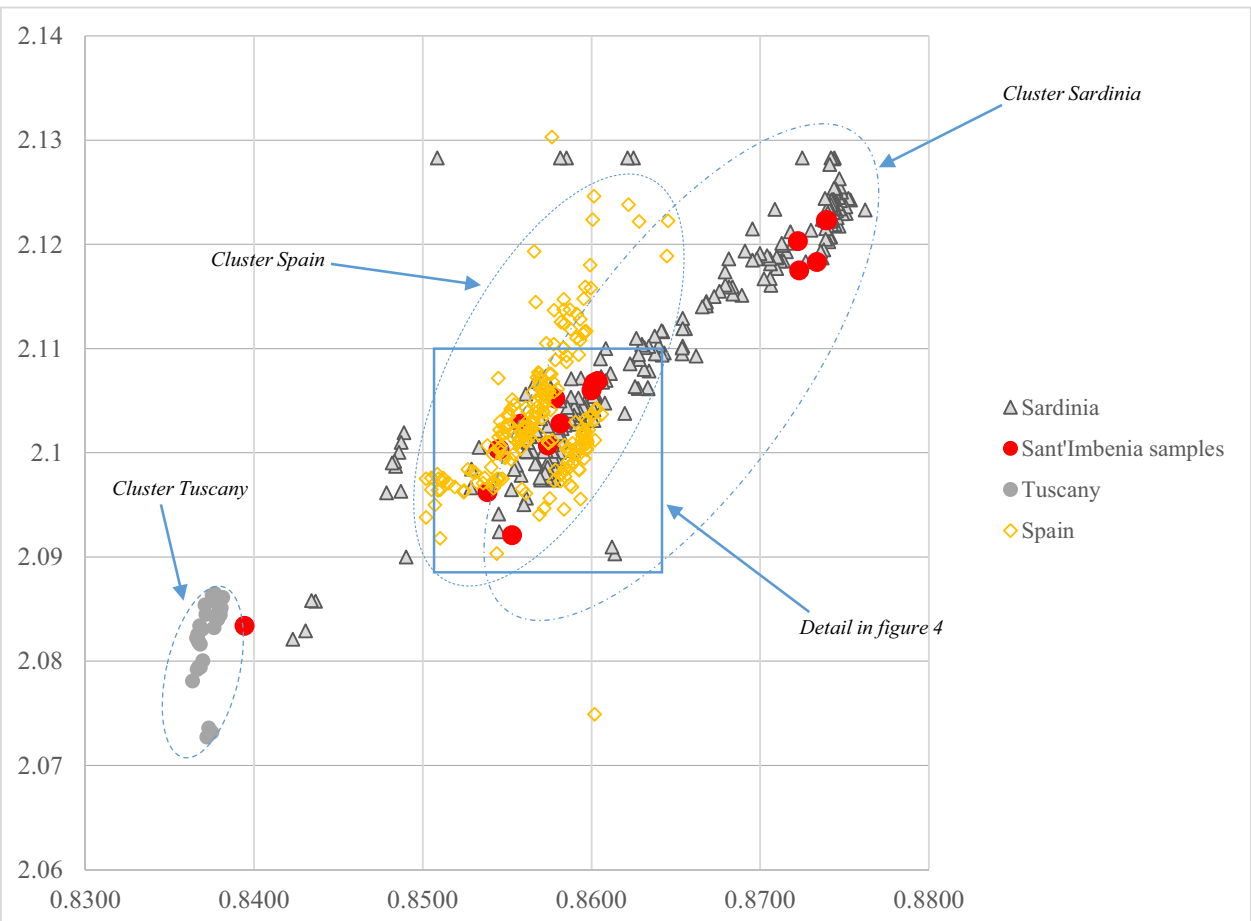

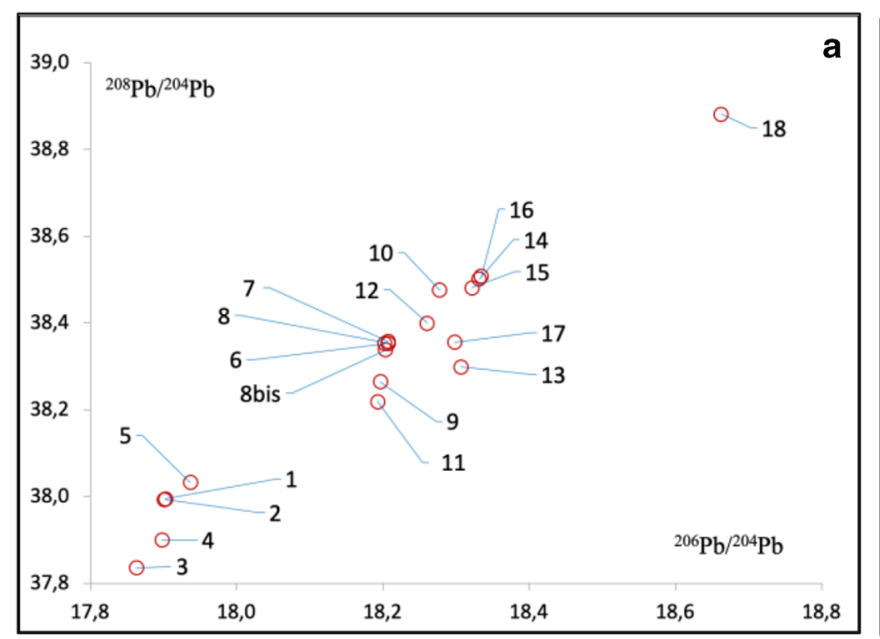

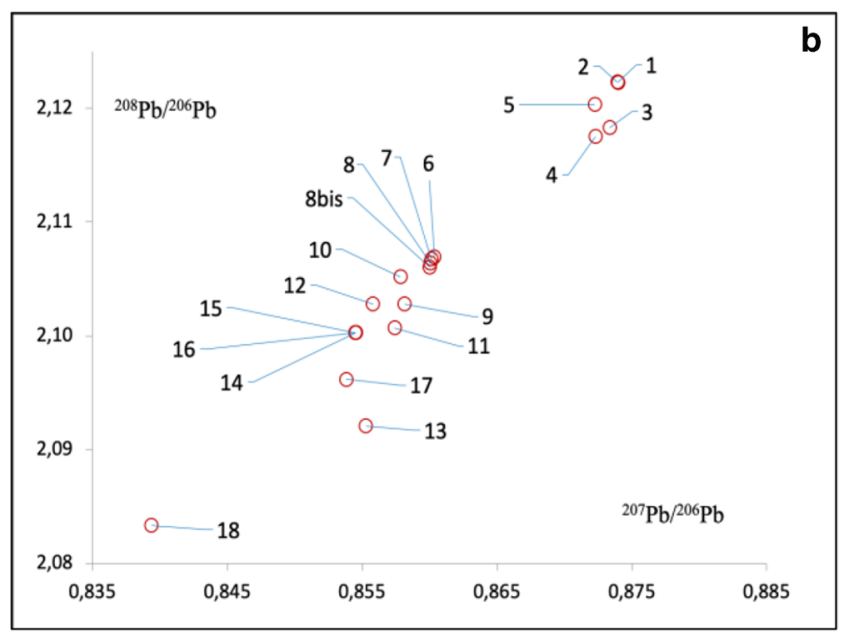

Fig. $3 \mathrm{a}-\mathrm{b}$ Common-denominator diagrams $\left({ }^{204} \mathrm{~Pb}\right.$ and $\left.{ }^{206} \mathrm{~Pb}\right)$ displaying the Sant'Imbenia samples

Taking into account the geographical location of Sant'Imbenia, the relation and compatibility of the metal objects with possible sources were explored: firstly the ore areas in Sardinia, then in other Mediterranean areas. Figure 2 shows the distribution of the 18 samples among the mining regions cited in the archives used in this article.

One extremely important point to always bear in mind is that all of these databases, despite their large collection of samples, are by definition incomplete. First of all, present-day outcrops are not exhaustively charted. Metre-sized outcrops, which could have supplied a few tons of ore, may well be hidden below vegetation or modern buildings or in presently inaccessible areas. Secondly, ore showings evident in the Nuragic era may have been exhausted over the centuries and hence no longer appear on maps. Thirdly, it is a well-known fact that the PbIC of minerals in a single mine are variable at the $\mathrm{cm}$ scale and at the $10 \mathrm{~m}$ scale (e.g. Kang et al 2020, and references therein); unless one analyses the entire mineralized volume of a mine, it is impossible to eliminate the doubt that one mineral that was not sampled could be isotopically 
Fig. 4 Boxplot showing trace element distributions of Sant'Imbenia lead samples measured with neutron activation analysis (for detail see Romanò 2016)

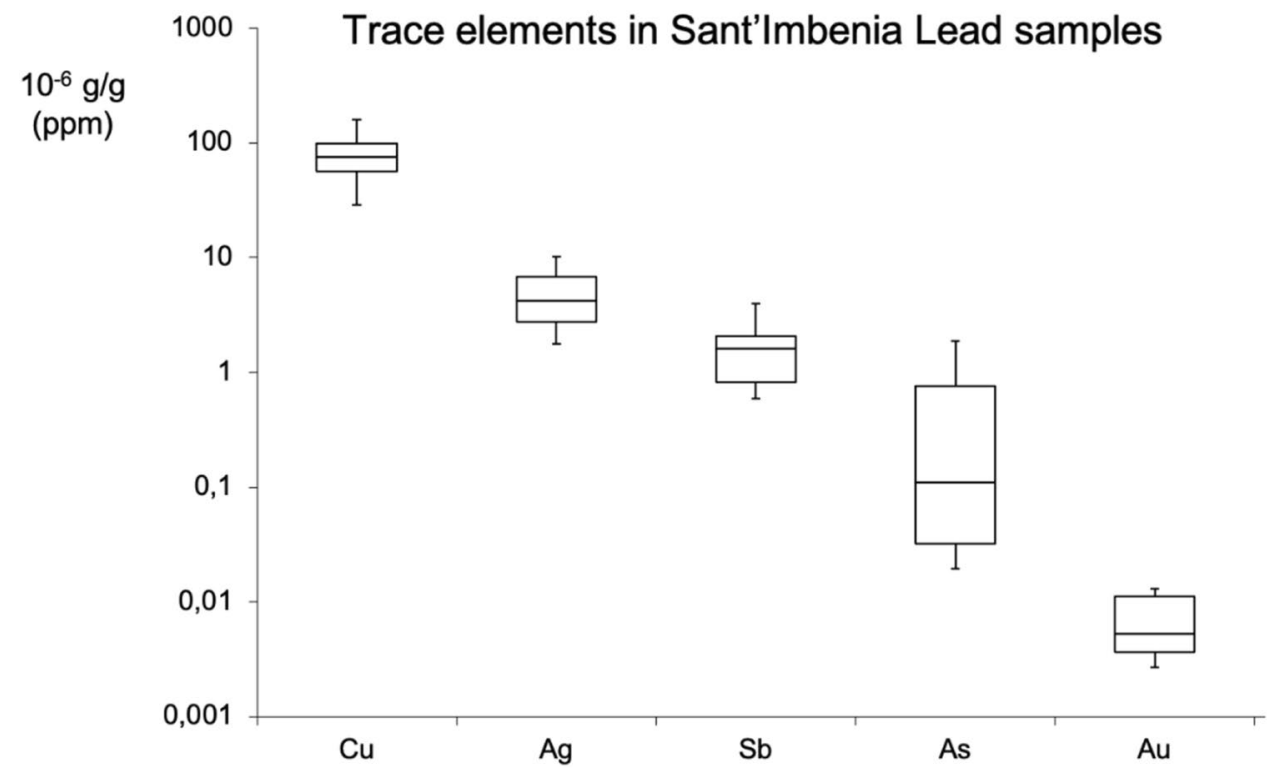

different from those that were. Another source of ambiguity is the frequent practice of recycling metals and mixing ore batches from different ore deposits. In the common-denominator diagrams displaying data, all "binary" mixtures (mixtures between $\mathrm{N}$ end-members lie in a polygon with $\mathrm{N}$ vertices) are manifested as linear segments connecting the two mixing end-members; mixtures always lie between the pure end-members. Figure 3a-b show the common-denominator diagrams for the isotopes 204 and 206.

Lead can also be considered a clue for the extraction of silver, separated by cupellation from galena, richly found in Sardinia (Pearce 2018). One aspect that has not yet be clearly settled is if cupellation was a widespread practice at the time of the Sant'Imbenia emporium. According to Perelló and Llull (2019), the invention of cupellation is ascribed to the Phoenician colonists after the eighth and seventh centuries. Thus, the observation that the lead objects in Sant'Imbenia have low silver concentrations (see Fig. 4 and Table 3 in Appendix) can point to an earlier invention of cupellation than in the Balearic Islands, but can also be due to the mining of Ag-poor galena, as is observed in presentday ore deposits (e.g. Kang et al 2020).

Bearing in mind these caveats, it is possible to reliably assign a SW Sardinian provenance to five samples shown in Table 1 (those falling in the range $0.87176 \leq{ }^{207} \mathrm{~Pb} /{ }^{206} \mathrm{~Pb} \leq 0.8742$, $2.1187 \leq{ }^{208} \mathrm{~Pb} /{ }^{206} \mathrm{~Pb} \leq 2.1244$, typical of Early Paleozoic mineralizations). These $\mathrm{PbIC}$ ranges perfectly overlap with the mines of Buggerru, San Giovanni Bindua, Domusnovas and Carreras, all in the Sulcis-Iglesiente-Fluminese areas in the SW Sardinia. From our Sardinia database, 28 samples with isotopic ratios ${ }^{207} \mathrm{~Pb} /{ }^{206} \mathrm{~Pb}$ and ${ }^{208} \mathrm{~Pb} /{ }^{206} \mathrm{~Pb}$ close to the five samples were selected within the following ranges (see Table 4 in Appendix). This PbIC signature cannot be explained by anything other than a direct derivation of these five metal objects from the above mines. If they were to be interpreted as recycling-cum-mixture, one would have to hypothesize an end-member lying further towards higher ${ }^{207} \mathrm{~Pb} /{ }^{206} \mathrm{~Pb}$ and ${ }^{208} \mathrm{~Pb} /{ }^{206} \mathrm{~Pb}$ ratios, which is however not found in the Western Mediterranean (Fig. 5).

The match with the two mines in the Iglesiente district, Buggerru and San Giovanni Bindua, is almost total: despite being about $30 \mathrm{~km}$ apart, the two mines have exploiting veins with very similar isotopic ratios (see Table 5 in Appendix). While samples 3 and 4 can be matched with two mines in the Iglesiente district (Domusnovas and Carreras), sample 5 does not fit any isotopic ratio even if it is clearly attributable to the Sulcis area.

The situation for the 13 samples (6-17) lying in the centre of Fig. 2 is more complex: in this part of the diagram, it is possible to observe the overlap of the PbIC of some Sardinian and Iberian mines.

Figure 6 shows a detail of the selected area in Fig. 2: among the twelve samples, the top four on the right are compatible with Sardinian ores: the dotted line delimits an area in which the Iberian mines become predominant.

Four of the samples, 6 to 8 bis, falling in the range $0.8600 \leq{ }^{207} \mathrm{~Pb} /{ }^{206} \mathrm{~Pb} \leq 0.8604,2.1060 \leq{ }^{208} \mathrm{~Pb} /{ }^{206} \mathrm{~Pb} \leq 2.1069$, typical of Late Paleozoic mineralization, overlap with the Montevecchio mine, in the Arburese area (W Sardinia).

In Fig. 7 the total overlap with the Montevecchio area (Arbus) and a partial overlap with a few samples from the Rio Tinto 


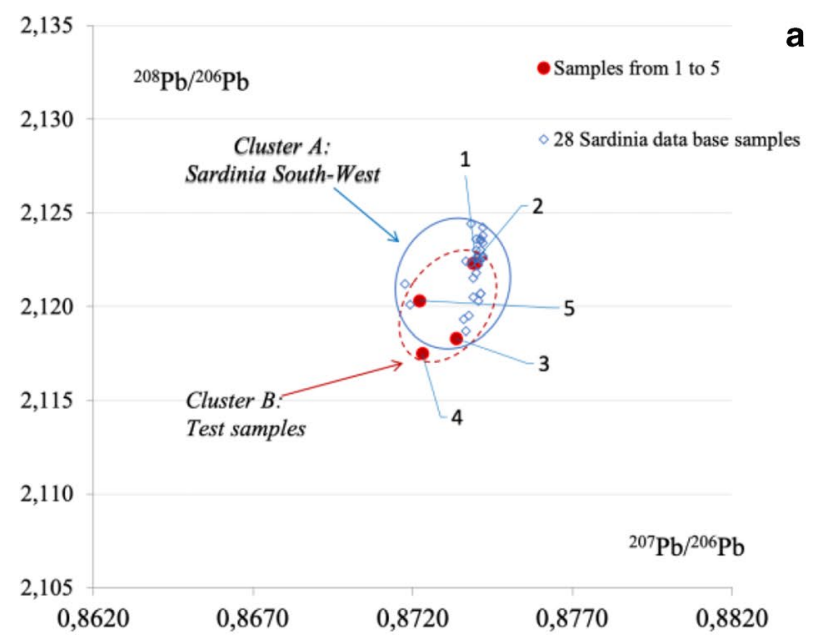

a

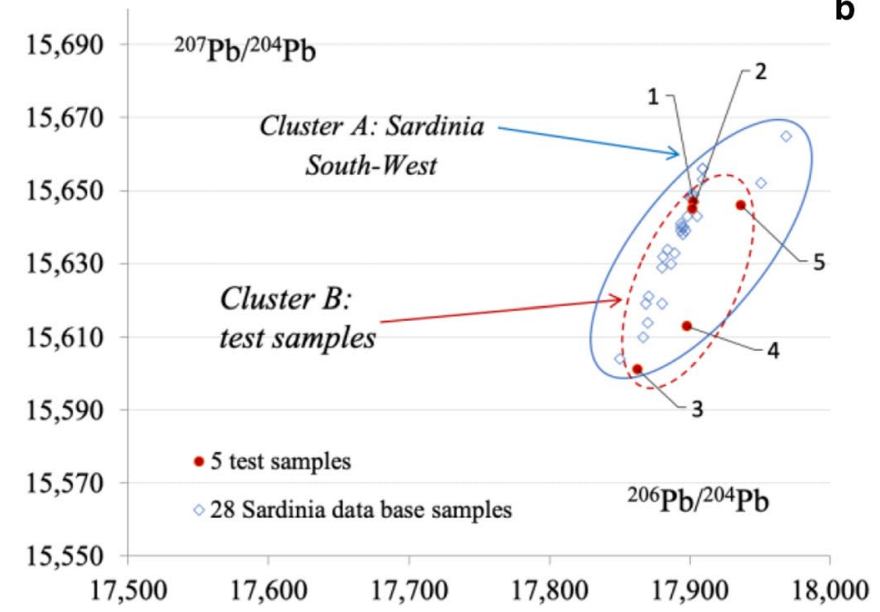

Fig. 5 a-b Distribution of 5 samples from S. Imbenia (dark circles) and 28 values (light diamonds) from Sardinian mine districts of the Fluminese-Iglesiente areas isotopically nearer to the first ones. Samples from 1 to 5 as listed in Table 1

district (Huelva, S Spain) can be observed at the very end of the cluster (see Table 6 in Appendix).

The remaining samples (9-13 of Table 1) present $\mathrm{PbIC}$ values $\left(0.8553 \leq{ }^{207} \mathrm{~Pb} /{ }^{206} \mathrm{~Pb} \leq 0.8582\right)$ that overlap with several Late Paleozoic-Early Triassic mineralizations in the circum-Mediterranean region. These include S Iberia but also small and very small ore showings in Sardinia (Argentie-ra) Gale and Stos Gale 1987; 1988;
Barbagia-Nuorese: Stos Gale et al. 1995; Gerrei-Sarrabus: Stos Gale et al. 1995) that cannot be part of the previous cluster (Fig. 9).

It is not vital for the present discussion to determine all possible minor ore sources, as recycling and mixing of metal batches of disparate origins needs to be taken into account (see also "Discussion" below).
Fig. 6 Detail of Fig. 2, Iberian and Sardinian ores

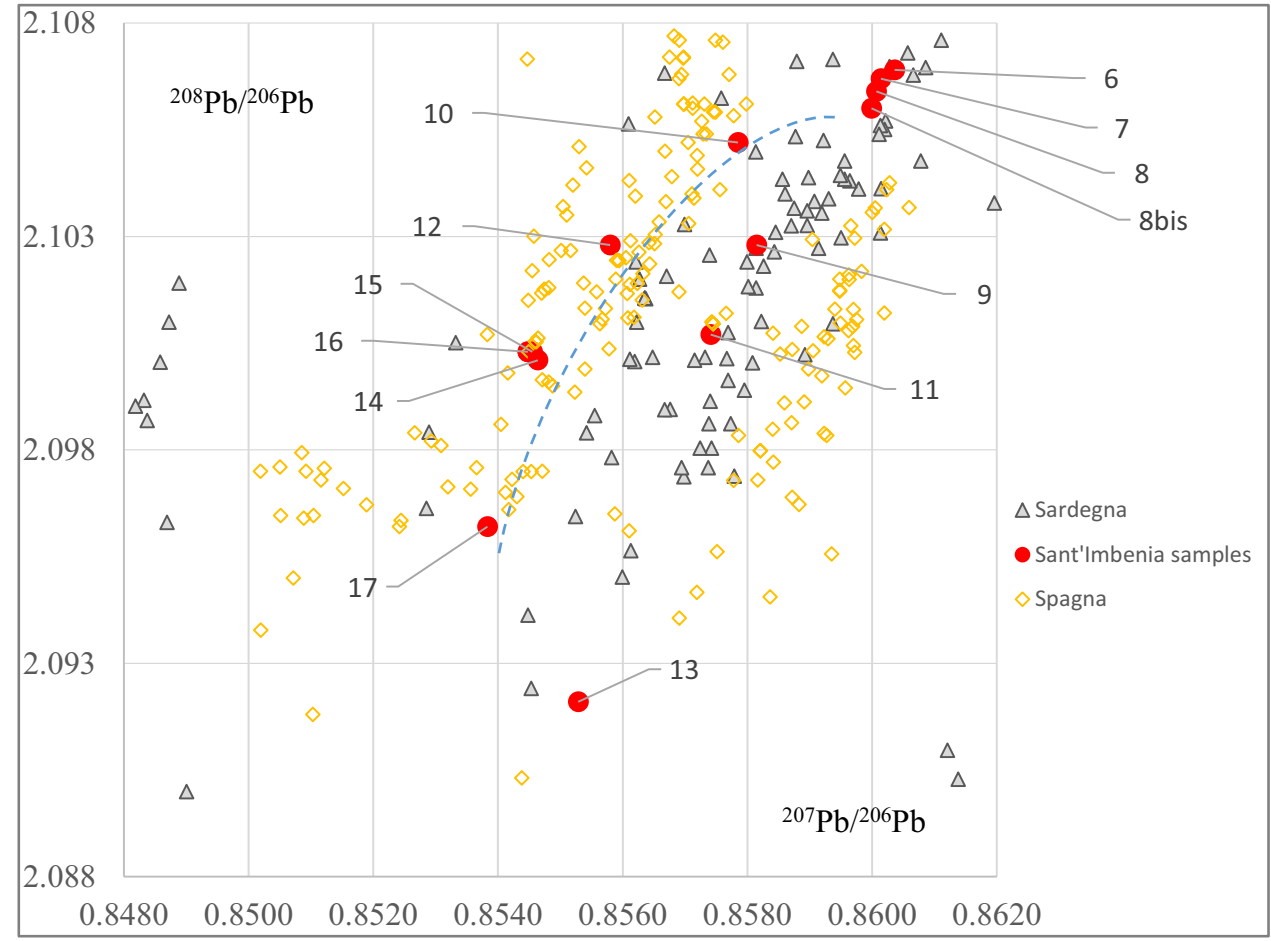


Of notable interest is the cubic weighing standard (samples 8,8 bis). Its mass, ca. $47 \mathrm{~g}$, relates to both Aegean and Levantine weight systems (see infra in "Archaeological Conclusions"). We have analysed both the discoloured surface and an interior piece, as alteration patinas and unaltered interiors could be a priori isotopically different. Only after the measurement we were able to determine that the mass balance of the alteration produced a negligible isotopic bias. The analyses of its weathering crust and of the unaltered interior coincide, indicating that the measured PbIC was not perturbed during the last 2800 years. The purpose of this standard was certainly not the weighing of agricultural products (which would have been traded at least in the kg range) and could refer instead to the weighing of small amounts of products such as herbs for medical use and/or spices, milk thistle and fenugreek, which was found in a repository (A48) and today it is extremely abundant in North Western Sardinia (Marino 2014: 49-58) (Fig. 8).

Samples 9-13 have shown compatibilities coherent with Sardinian districts (see Tables 7-10 in Appendix).

Samples 9 and 11 have their compatibilities with the Sulcis District because of the isotopic ratio $207 \mathrm{~Pb} / 206 \mathrm{~Pb}=0.85624$, which is the highest in the area (see Table 7 in Appendix). Different geographic provenances have to be found for the samples 12 and 13. Figure 9 highlights the compatibility between samples 9 and 11 (two laminae) and some mines in the Sulcis district.
The three samples (9-11) should be analysed in relation with other mine districts and it is possible to observe that: for sample 10, a different provenance can be assumed and different mines have similar lead isotopic composition. L'Argentiera (Sassari) is one of them but there is not a sufficient homogeneity of the isotopic ratio values to assign the sample with certainty to this area. Another mine in SE Sardinia, Pranu 'e Sanguini, in the Gerrei-Sarrabus region, offers a similar but not overlapping isotopic composition, as can be seen in Fig. 9. The mean of the other samples is notably different (Es. $\left.{ }^{207} \mathrm{~Pb} /{ }^{206} \mathrm{~Pb}=0.85624 \pm 0.0009\right)$ : for this reason, the compatibility cannot be deemed sufficient (see Tables 8 and 10 in Appendix).

The remaining samples (12 and 13) have PbIC signatures typical of Cenozoic mineralization. The most prominent Cenozoic ores are found in the Catalan Coastal Ranges District near Tarragona. This district is characterized by many large and small mines with $\mathrm{Pb}$ isotopic ratios $0.8548 \leq{ }^{207} \mathrm{~Pb} /{ }^{206} \mathrm{~Pb} \leq 0.8565$, $2.0994 \leq{ }^{208} \mathrm{~Pb} /{ }^{206} \mathrm{~Pb} \leq 2.1027$ (see Table 9 in Appendix). However, small and poorly charted showings in NW Sardinia (e.g. Calabona and Bonu Ighinu: Begemann et al 2001) also should be considered possible sources. It is very important to note that the question of provenance must never be asked as "which mining district has an average isotopic composition closest to the investigated sample", as the correct question is instead "which
Fig. 7 Detail of Rio Tinto and Arburese clusters

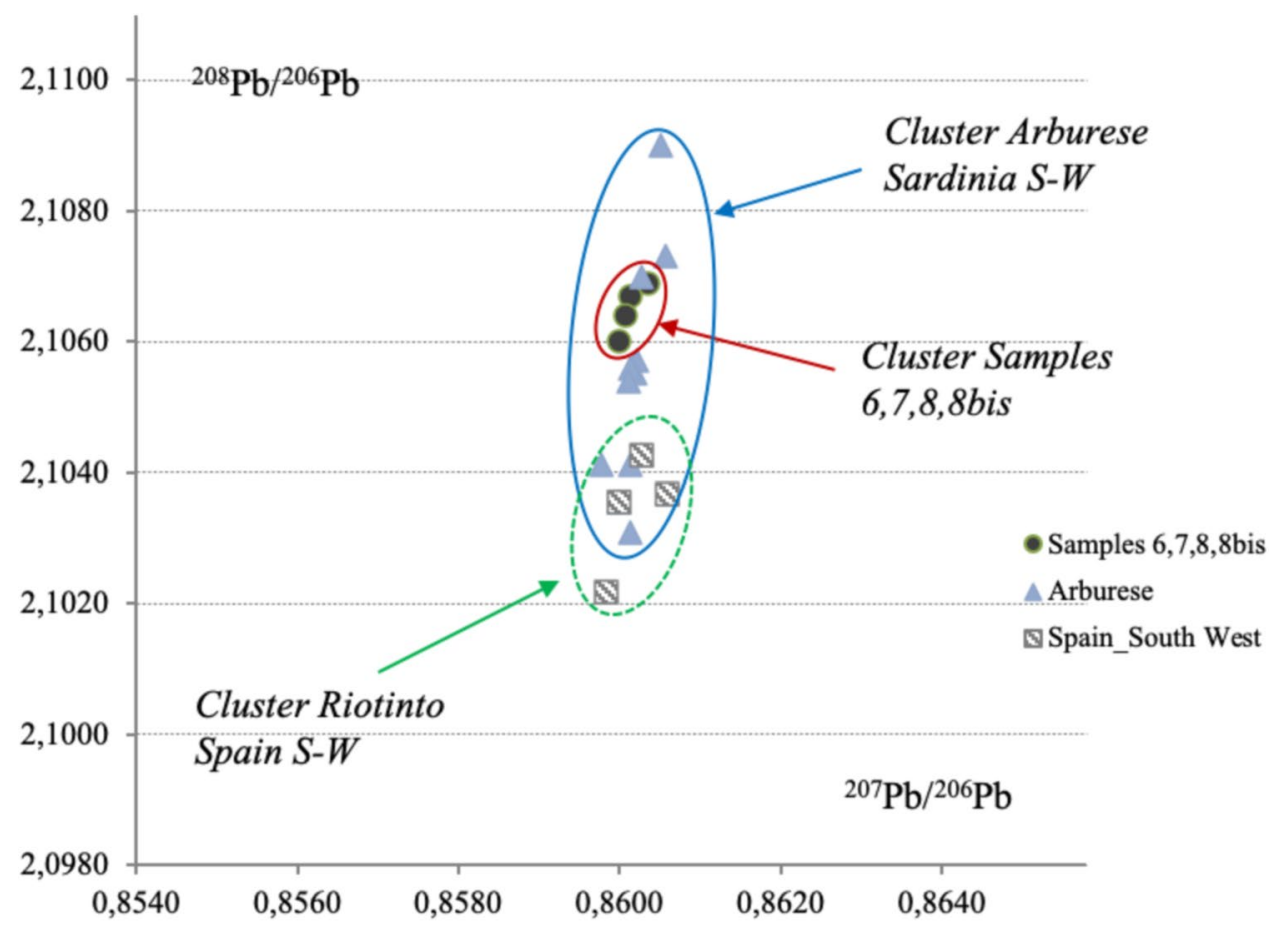


Fig. 8 The weight from A48, US 396 (photo M. Rendeli)

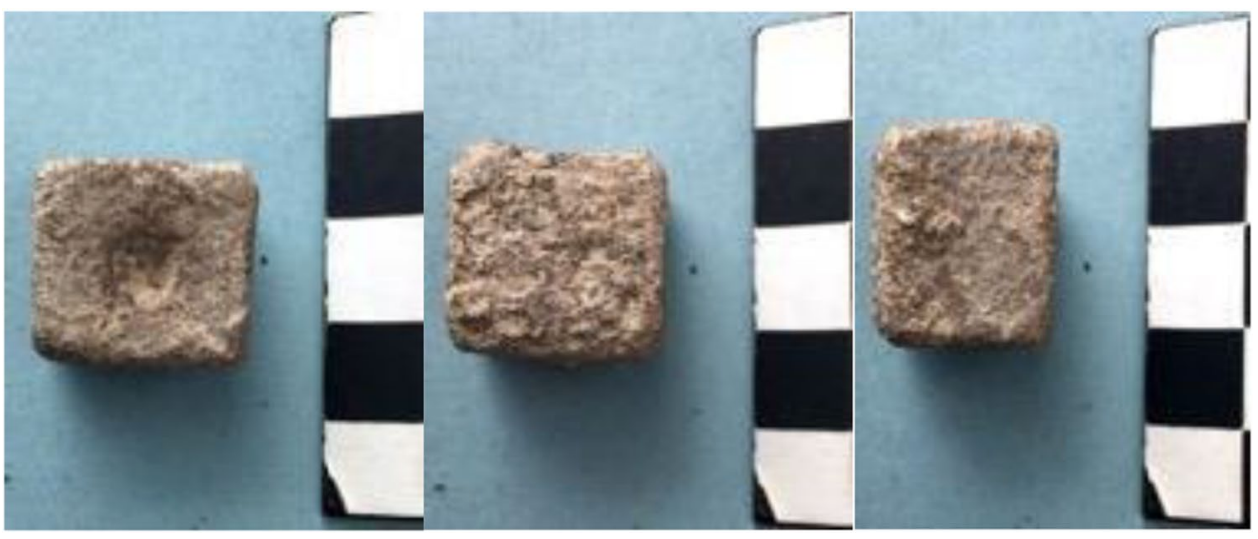

mining district has at least one data-point that coincides with the investigated sample". Thus, one single small outcrop from W Sardinia might be the true source of one object, even if hundreds of ores from all over the world also have the same PbIC.

Samples 12 and 13 lie outside the database of isotopic ratios collected for the Sardinian mines: Fig. 9 shows values on which the clusters are built (see Tables 9-11 in Appendix), distinguished for different districts in Sardinia. Since $\mathrm{Pb}$ isotope analyses are not an unambiguous proof of provenance but an indication of compatibility, it is very important to avoid proposing a Sardinian origin basing on purely isotopic grounds, but to include the independent, nonisotopic, archaeometric/archaeological context.

Using the same criteria, other Mediterranean mines are taken into consideration, with appropriate isotopic ratios in order to research compatibilities for samples 12 and 13, adding also sample 10 to verify its origin.

From our research emerges that the Catalan Coastal Ranges District may offer three interesting areas in the inland of Tarragona (from NE to SW): Ulldemolins, Priorat and Tarragona (see Table 9 in Appendix).

This district is characterized by a series of small mines with isotopic ratios: $0.85477 \leq 207 \mathrm{~Pb} / 206 \mathrm{~Pb} \leq 0.85646$
Fig. 9 Representation of different Sardinian clusters and possible overlap with Sant'Imbenia

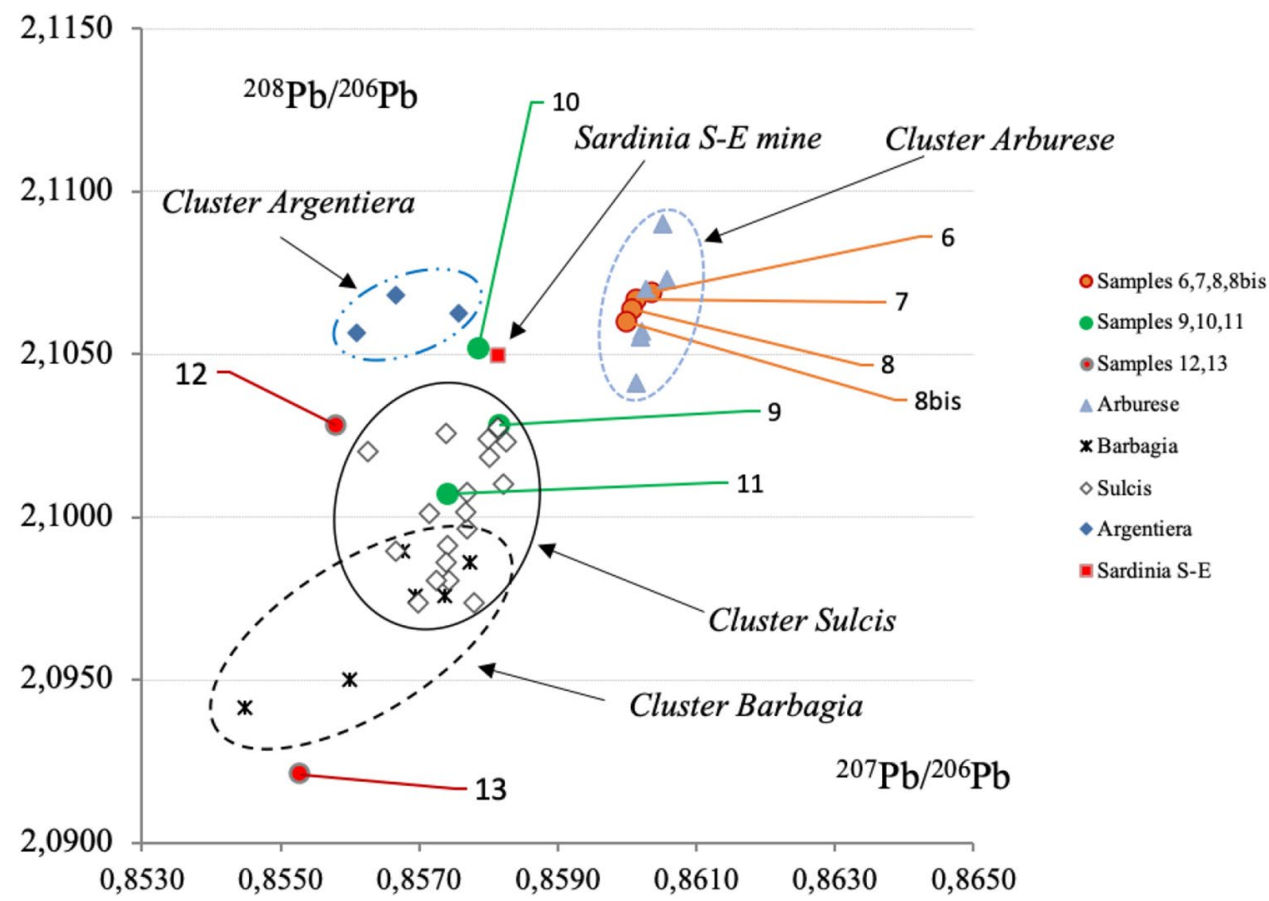


Fig. 10 Overlap of samples 10 and 12 with Sierra Morena and Catalan Coastal Ranges

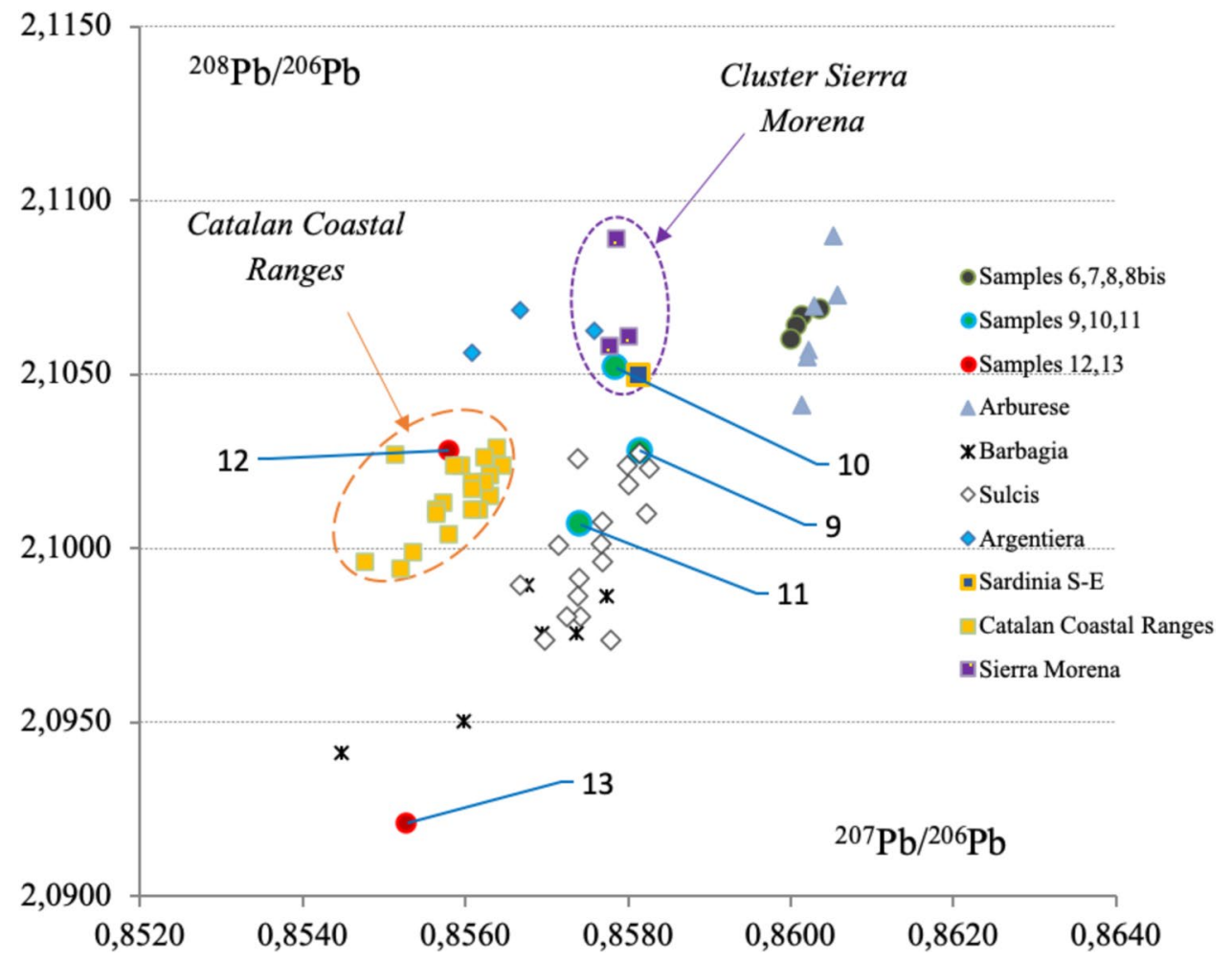

Fig. 11 Overlap of samples 13, 14, 15, 16 and 17 with Funatana Raminosa, CCR2 and Spain S-E clusters

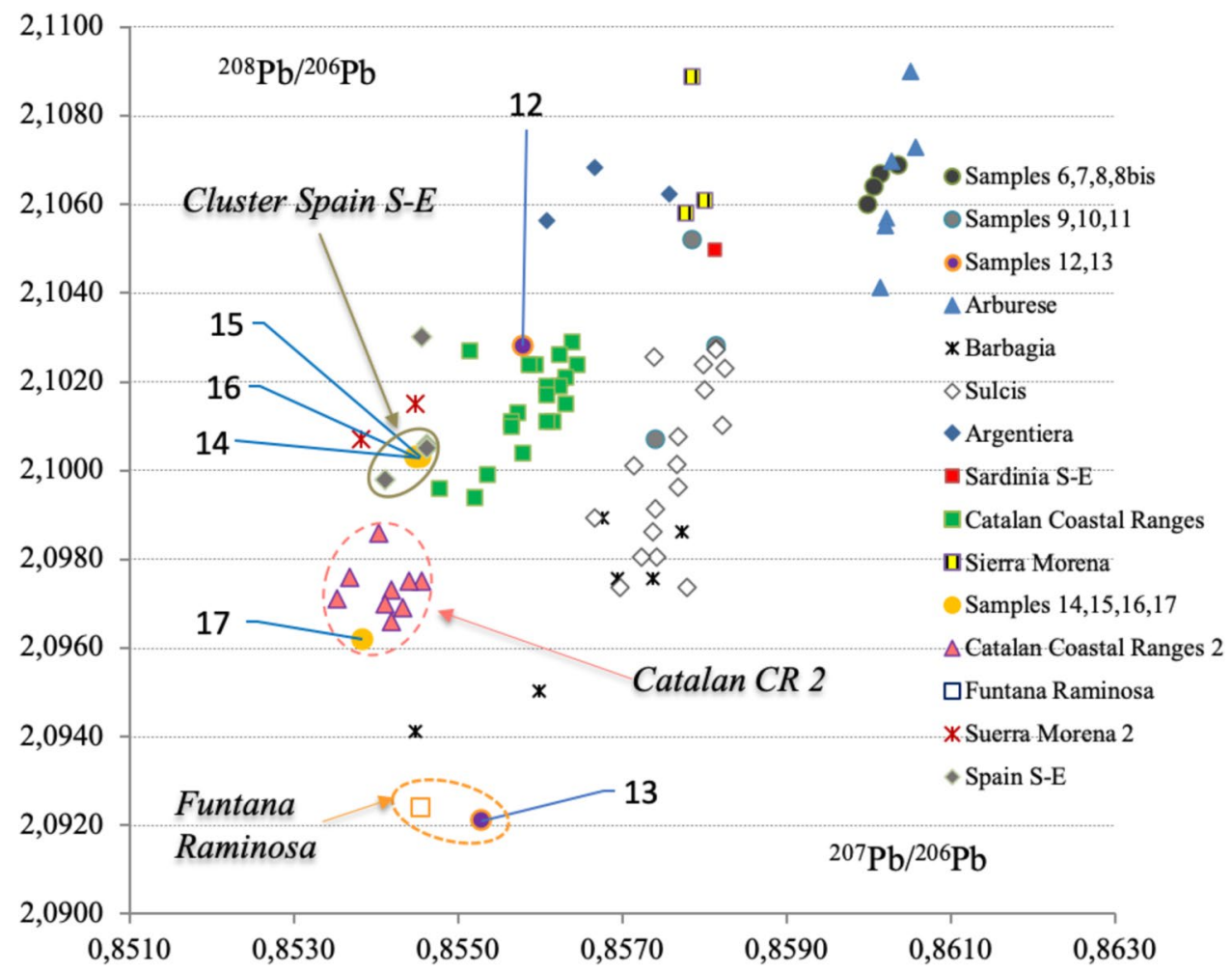


Table 2 Possible compatibilities for the provenance of lead from the excavations of Sant'Imbenia (Porto Conte, Alghero, Sardinia)

\begin{tabular}{|c|c|c|c|c|c|}
\hline \multirow[t]{2}{*}{ No } & \multirow[t]{2}{*}{ Sample } & \multirow[t]{2}{*}{ Object } & \multicolumn{3}{|l|}{ Origin } \\
\hline & & & Region & Mine districts & Mine site \\
\hline 1 & SI_2013_A47_U832 & Cubic weight & Sardinia & Sulcis-Iglesiente & San Giovanni \\
\hline 2 & SI_2010_A24_US51 & Clamp & Sardinia & Sulcis-Iglesiente & Buggerru \\
\hline 3 & A24 US404 & Lamina & Sardinia & Iglesiente-Domusnovas & Marganai \\
\hline 4 & A50 US111 & Plaque & Sardinia & Sulcis-Iglesiente & Carreras \\
\hline 5 & SI_2012_A18_US434 & Lamina & Sardinia & Sulcis-Iglesiente & - \\
\hline 6 & SI_2009_A47_US52 & Clamp & Sardinia & Arburese & Montevecchio \\
\hline 7 & SI_2013_A48_US829 & Lamina & Sardinia & Arburese & Montevecchio \\
\hline 8 & A48 US396 & Cubic weight & Sardinia & Arburese & Montevecchio \\
\hline 8bis & A48 US396 & Cubic weight ext & Sardinia & Arburese & Montevecchio \\
\hline 9 & A52 US675 & Lamina & Sardinia & Sulcis & Sulcis, Rosas Narcao (SU) \\
\hline 10 & A49 US1100 & Clamp & Sardinia /(Spain) & Sardinia S-E /Sassarese & Sarrabus Gerrei / Argentiera \\
\hline 11 & A44 US798 & Lamina & Sardinia & Sulcis/Barbagia & Funtana Raminosa \\
\hline 12 & A52 US505 & Lamina & Spain & Catalan Coastal Ranges & - \\
\hline 13 & A47 US135 & Lamina & Sardinia & Barbagia & Funtana Raminosa \\
\hline 14 & SI_2011_A47_US175 & Object & Spain & Almerìa & Sierra Alhamilla \\
\hline 15 & SI_2013_A16_US923 & Lamina & Spain & Almerìa & Sierra Alhamilla \\
\hline 16 & SI_2015_A29_US1372 & Lamina & Spain & Almerìa & Sierra Alhamilla \\
\hline 17 & E1 US1246 & Clamp & Spain & Catalan Coastal Ranges & - \\
\hline 18 & SI_2008_US1_SO & Clamp & $\begin{array}{l}\text { Spain } \\
\text { Italy }\end{array}$ & $\begin{array}{l}\text { Castellòn/Cartagena-Mazarron } \\
\text { Tuscany }\end{array}$ & - \\
\hline
\end{tabular}
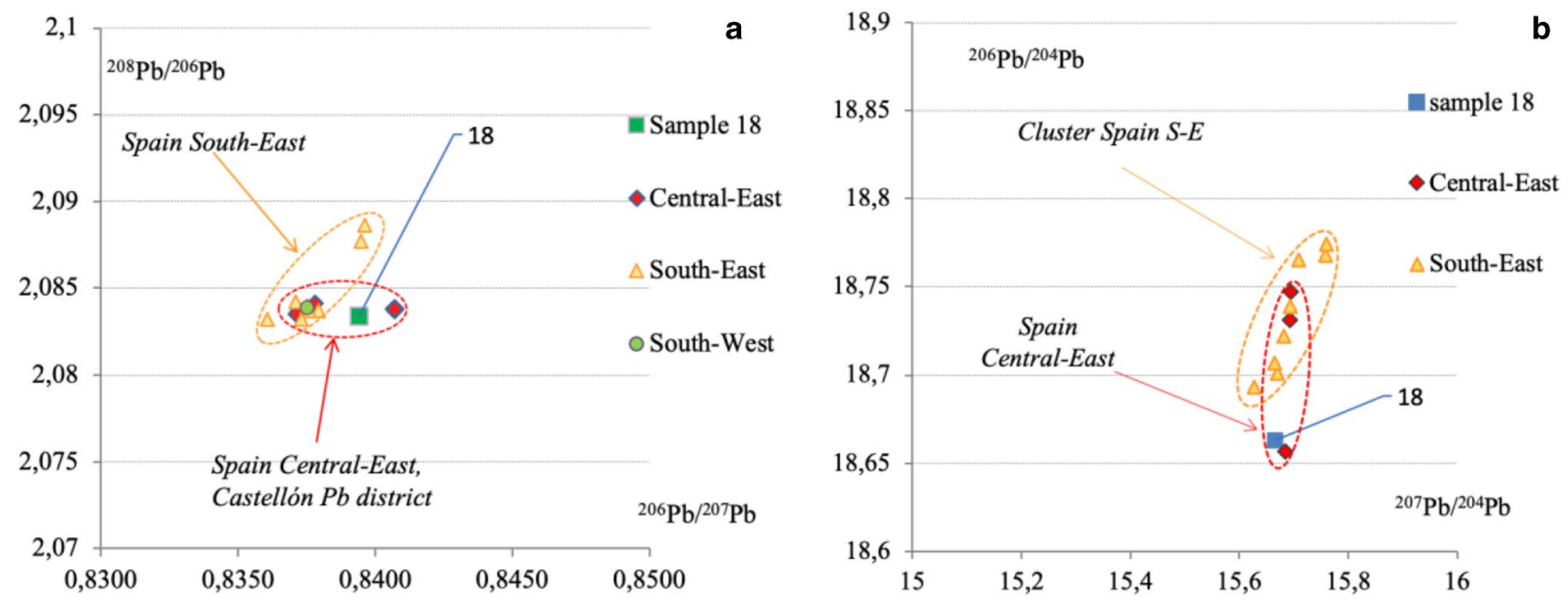

Fig. 12 a-b Overlap of sample 18 with Central-East Spain cluster created with the isotopic ratios j/206 and j/204

and $2.0994 \leq 208 \mathrm{~Pb} / 206 \mathrm{~Pb} \leq 2.1027$. We can add some mines from the Sierra Morena (see Table 10 in the Appendix) and, in Sardinia, the Barbagia District the mine of Funtana Raminosa (see Table 11 in the Appendix).

Some of the samples are from the Sierra Morena (Spain) mines, and these can be placed near our sample 10 creating a small cluster, which includes other mines from $\mathrm{N}$ and $\mathrm{S}$
Sardinia that have already been discussed. Even with these data, the attribution of sample 10 remains quite dubious: the Sardinia reference is precise but weak for its unicity, the samples from Sierra Morena may represent its origin but without complete certainty. On the contrary, for sample 12, its inclusion in a cluster made up of many samples suggests the high probability that the mineral is from the mines of the 
Catalan Coastal Ranges. Among the mines of this district, the Raimunda mine shows the best compatibility. Sample 13 remains in isolation in Fig. 10 with no contribution to determine its geographic origin: its isotopic signature, if placed in the overall distribution (Fig. 2), finds some marginally compatible isolate mines.

Samples 14 to 17 , with isotopic ratios $0.85383 \leq 207 \mathrm{~Pb} / 206 \mathrm{~Pb} \leq 0.85455$ and $2.0962 \leq 208 \mathrm{~Pb} / 206 \mathrm{~Pb} \leq 2.1003$, constitute a homogenous group: samples 14,15 and 16 are almost identical while the fourth, 17, differs only slightly. Figure 11 shows the mines with compatibilities the value of our samples, mainly from the Western Mediterranean basin (see Table 12 in Appendix).

Samples 14, 15 and 16 have almost identical isotopic values and in Fig. 11 overlap in one circle (orange in the SE Spanish cluster): this cluster is composed of the minerals from the mines of SE Spain, the district of AlmeriaSierra Alhamilla in particular, which assure a complete compatibility between the isotopic ratios of our objects and those coming from these mines.

As regards sample 17, despite the apparent similarity of its isotopic ratios with those of the previous ones, it has a different origin mostly due to the isotopic ratio $208 \mathrm{~Pb} / 206 \mathrm{~Pb}$. In Fig. 11, sample 17 lies in a lower area and forms a distinct cluster with some minerals coming from different mines of the district of the Catalan Coastal Ranges.

The last sample (18), with an isotopic ratio $207 \mathrm{~Pb} / 206 \mathrm{~Pb}$ that is much lower in comparison with the others, differs from the whole group.

Better compatibility is offered by a mineral extracted in the district of Castellòn, Plana Alta, which lies on the eastern coast of central Spain (see Table 13 in Appendix): it must be said that in the same district all the mines have different isotopic ratios, closer to those found in the southern area of Cartagena-Mazarròn. In Fig. 12a-b, the set of points to the left of sample 18 represents established mine districts on the E coast, from the Valencian area of the Andalucia. Figure 12b, created with the isotopic ratios $j / 204$, also offers the same interpretation.

Table 2 summarizes the results of the possible compatibilities for the provenance of lead of all the objects reported in Table 1, which are from the excavations of Sant'Imbenia (Porto Conte, Alghero, Sardinia). For all of them, apart from sample 10, the regional origin is certain, the mine district or the mine itself is not defined for all the samples, but their geographic provenance is identified.

Finally, the provenance of sample 18 is especially intriguing, as its PbIC falls at the intersection of the field defined by ores from Etruria (Villa and Giardino 2019) with those from the Catalan Coastal Range (see Fig. 2).
No corresponding Sardinian ore has yet been reported and this suggests that in either case the arrival of this object in Sardinia involved maritime trade. Mixing is out of the question, as the ores from Etruria have an extreme $\mathrm{PbIC}$, unmatched by other circum-Mediterranean mining regions, and therefore might qualify as end-members, but not as products, of metal mixing.

\section{Discussion}

Notwithstanding all the doubts that surround the assignment of provenance on an individual basis, we can draw some robust and some tentative conclusions regarding the extension of the trade network of Sant'Imbenia.

The circulation of lead is also important because it testifies, indirectly, the organization of local communities in those districts: it opens a new picture on the relations among different areas of the island, all under control of local communities, whose political and economic organization is not known and has to be analysed and understood. Lead is clearly not a precious metal, but its economic importance stems precisely from its low cost: in contrast to gold, it can be used to repair broken ceramics, or to produce low-cost jewellery (e.g. Balassone et al 2002). Circulating lead quantities are higher than in previous periods and the communities should have a different organization, a network on which the vitality testifies a real change, their participation to an internal as well as to international trade and strong relation existing at a regional scale among different political and economic structures. It means also organization of a chaîne operatoire that starts from the mines and finishes to the objects and their circulation. The control of the mines in this long period (ninth to the middle sixth centuries BC) should have been in the hand of the local communities, which may have been changed their organization with the aim of responding to all the requests.

The first unexpected, but very robust result is that a substantial proportion of the analysed metal objects derives from the SW Sardinia (Sulcis, Iglesiente and Arburese). Travelling this distance for protohistoric sailors was long and dangerous; overland transport was likely even more arduous. Sant'Imbenia thus was not just a marketplace for goods from the immediate hinterland. A second robust result is that at least one object is incompatible with any Sardinian mining district and thus must have been imported by sea, in particular from Iberia (or perhaps from Etruria, see Fig. 2, Villa and Giardino 2019).

One probable (although not rigorously demonstrated) result is that the coastal ranges of Iberia (Rio Tinto, 
Almería, Tarragona) are very likely to be the sources for a substantial proportion of the metal objects, even if other, intra-Sardinian sources (Argentiera, Barbagia) are both archeologically and isotopically possible. Furthermore, metal recycling/mixing cannot be excluded.

It is important to bear in mind that, as mentioned above, some individual ore sources may be missing from the databases. Furthermore, any object could be the result of two common metallurgical practices: smelting of ore from different sources and resmelting of recycled objects. In both cases the origin is destined to remain ambiguous.

\section{Archaeological conclusions}

The analysis and the results stemming from the isotopic ratios of the objects from Sant'Imbenia in comparison with Sardinian and Mediterranean mining districts or sites provide us with important material to determine the origin and circulation of lead from the ninth to the middle sixth century BCE (Giardino and Lo Schiavo 2007).

The centrality of the site in the Iron age is confirmed by the huge amount of copper slags found in four repositories for some $140 \mathrm{~kg}$ : the slags found in two repositories of A23 were analysed by C. Giardino e F. Lo Schiavo together with the one found at Nuraghe Flumenelongu: isotopic measures on lead found in copper show that the provenance of the copper could be diverse (Greece, Cyprus, Tuscany) but part of it could come also from Calabona, nearby Alghero, $20 \mathrm{~km}$ south from Sant' Imbenia (Giardino and Pinarelli 2007: 99-109). The mine of Calabona was known in antiquity also for the copper extracted here and exported in Rome to realize the bronze Lupa Capitolina, a discussed masterpiece of the Etrusco-Roman art of the end of the sixth-beginning of the fifth centuries BC (Gale et al 2005: 131-137): these data, together with the pottery finds, show the centrality of the Alghero in the first half of the first millennium BC and in it the role of Sant'Imbenia was central for trade and commerce (Gale et al 2005: 138-139; Rendeli 2018).

Far from the archaeology of repositories or hoards, of slags and ingots, these samples may add new data and tesserae to realize a more complete mosaic of the relations between north-western Sardinia, other districts of the island and the Mediterranean area: they are all fragments taken from small objects belonging to the same collection, mainly clamps but also a couple of weights, which may have had a wide circulation in the Mediterranean area (Giardino 1992: 304-316; 2010: 161-177). For all the objects analysed, it is possible to affirm that they have ended their "social life and circulation" at Sant' Imbenia but we cannot define how long these were. Being a market place it would not be surprising if it were to turn out that the lead used came from different provenances, both from Sardinia and other Mediterranean areas.

The lead ratios confirm the trend seen in other classes of material, e.g. pottery (De Rosa 2017) and amphorae (De Rosa and Garau 2016; De Rosa et al 2018): that of a wide interconnection with other districts of the island and other countries in the Central-Western Mediterranean. The meagre quantities of metal in question do not allow the construction of mercantile relations, such as could be the case for the copper with its four repositories $(130 \mathrm{~kg})$, but nevertheless they testify that at Sant'Imbenia there was a circulation of lead of different origin, from Sardinia and overseas (most probably Spain, possibly Etruria).

It is not a surprise that the cubic lead weight with a mark of value or a letter ( ${ }^{\mathrm{c}}$ ayin), found in A 48 in a layer dating to the first half of the eighth century BCE, has isotope ratios which indicates its origin from Montevecchio in the Arburense area (a cubic lead weight with the same mark from Cerro del Villar in an eighth-seventh c. BCE context weighs $14.187 \mathrm{~g}$ : Aubet 2002: 32). Its weight of $47 \mathrm{~g}$ makes it four times the Microasiatic shekel (11.75 g), five times the Syrian shekel of the Bronze age $(9.4 \mathrm{~g})$, six times the shekel of Karkemish (7.83 g), and seven times the Aegean unit (6.5-6.8 g). The multiplicity of ponderal relations (Zaccagnini 1991; Alberti et al 2006: 1-2; RuizGálvez 2003: 153-155; Lo Schiavo 2006: 367-379), all related to the Eastern and Central Mediterranean, while dissuading us from attributing the weight to any one system, suggests also that this artefact could have been used to "translate" between different ponderal unit systems. At the same time, it encourages the interpretation of Sant'Imbenia as an important "port of trade" and "gateway area" of NW Sardinia with other areas of the Mediterranean.

Many districts are involved all over Sardinia: Sulcis, Iglesiente, Fluminese, Arburese, Buggerru, Nuorese and perhaps also Nurra (Valera and Valera 2005: 35-42; Valera et al 2005: 43-88; Atzeni et al 2005: 160-172). Enlarging the picture, compatibilities between the Sant'Imbenia samples and some Spanish districts have been observed: the Catalan Coastal Ranges, the mine district in the hinterland of Almeria (Sierra Alhamilla) and, as a very remote possibility, the Rio Tinto district in Andalusia (Aguayo de Hoyos 2018; Hernández 2018).

All the districts are already known for the exploitation of their mines in antiquity, in Sardinia and Spain at least since the Bronze age. There is a wide and rich bibliography on the compatibilities between ancient objects and provenance districts for the Bronze and Iron age of 
Sardinia (Stos Gale et al 1995; Begemann et al 2001; Atzeni et al 2005; Gale 2006; Giardino and Lo Schiavo 2007), Italian peninsula (Zifferero 1998) and Spain (Craddock et al 1985; Stos Gale et al 1995; Renzi et al 2009, 2012; Rovira and Renzi 2013; Renzi and Rovira Llorens 2015). What is really interesting for Sardinia is the continuity of exploitation of mine districts during the Iron age also in phases which were prior to the establishment of Phoenician colonies in the island.

From an archaeological point of view there emerges, for the first four centuries of the first millennium BCE, a wide and dynamic organization of the exploitation of metals in many parts of the island and a wide circulation of lead inside and outside of the island.

This is quite important because the provenance could have been determined by new contacts and relations with other areas or districts: these contacts could be hypothesized on the basis of the lead found at La Fonteta (Renzi et al 2009: 2584-2596), in Spain, where the semi-worked metal from Catalan Coastal Ranges and from Sierra Alhamilla could have been accumulated in the site and then exported to Sant'Imbenia. These data strengthen the relation between the Iberian peninsula and Sardinia already attested by pottery and amphorae since the end of the ninth c. BC (Rendeli 2018).

Of great importance is the result that the isotopic values of many of the samples are compatible to a good degree with those of ores from mines or mining districts: this means that the lead was not mixed with metal coming from other mines; perhaps it was used once or reused without being blended.

The clamps, which in two occurrences were used to restore large storage vessels of local production, indicate that the lead could have been worked at Sant'Imbenia or in sites nearby. The lead could have arrived in a semiworked state, similar to the ingots found in the excavation of Sant'Anastasia at Sardara and other S Sardinian sites, then utilized locally to create objects (Ugas 1993: 25-35). While the huge number of laminae, possibly parts of clamps, could have been smelted in situ or nearby, different observations can be made for the two weights, whose metal could have been extracted at Bindua or Buggerru in the Iglesiente (sample 1) and at
Montevecchio in the Arburese district (sample 8, 8bis): their life could have been longer and they could have been brought into a Phoenician colony to become part of a set of weights which could have relations with different Aegean and Levantine ponderal systems.

The circulation of lead is also important because it testifies, indirectly, to the organization of local communities in those districts: it offers a new view of the relations among different areas of the island, all under the control of local communities, whose political and economic organization is not known and has yet to be analysed and understood. Quantities are higher in comparison with the previous periods and the communities must have been organized differently, into a network the vitality of which testifies to a real change: their participation in internal as well as international trade and strong relations existing on a regional scale among different political and economic structures. It means also organization of a chaine operatoire that starts from the mines and finishes with the objects and their circulation.

Lead can also be considered a clue for the extraction of silver, separated by cupellation from galena, of which there are rich deposits in Sardinia (Pearce 2018). Control over the mines in this long period (ninth to the mid-sixth centuries BCE) must have been exercised by the local communities, which may have changed their organization with the aim of responding to all the requests.

This means new ways of production, specialization and organization of work, perhaps with the same paths followed by potters, farmers or shepherds. The development of these mining activities in many areas of the island brings new light also to the definition of local organization, with or without the direct help of foreign merchants. The latter may also have triggered the endogenous transformations we can see at Sant'Imbenia or in many other areas all over the island, in the $\mathrm{S}$ part with the creation of the Phoenician colonies, in the NE part where the new discoveries at Tavolara, dated to the very early Iron Age, open important perspectives on the relation between the aristocracies of the newly formed Etruscan cities and of the Sardinian state organization (Casi 2018: 6-8; Di Gennaro 2019: 54-57). 


\section{Appendix}

Table 3 Trace elements of eight Sant'Imbenia lead samples

\begin{tabular}{|c|c|c|c|c|c|c|c|}
\hline Sample & US & $\begin{array}{l}\mathrm{Ag} \\
\mathrm{ppm}\end{array}$ & $\begin{array}{l}\text { As } \\
\text { ppm }\end{array}$ & $\begin{array}{l}\mathrm{Sb} \\
\mathrm{ppm}\end{array}$ & $\begin{array}{l}\mathrm{Cu} \\
\mathrm{ppm}\end{array}$ & $\begin{array}{l}\mathrm{Au} \\
\mathrm{ppm}\end{array}$ & $\begin{array}{l}\mathrm{Br} \\
\mathrm{ppm}\end{array}$ \\
\hline 3 & A 49 US 110 & $3.0 \pm 0.1$ & $0.179 \pm 0.013$ & $2.58 \pm 0.10$ & $55 \pm 7$ & $0.0112 \pm 0.0014$ & $1.4 \pm 0.2$ \\
\hline 4 & E1 US 1246 & $1.8 \pm 0.1$ & $\leq 0.02$ & $0.58 \pm 0.10$ & $77 \pm 9$ & $\leq 0.0029$ & $\leq 0.06$ \\
\hline 9 & A 50 US 112 & $10.1 \pm 0.5$ & $\leq 0.05$ & $0.83 \pm 0.10$ & $270 \pm 21$ & $\leq 0.0045$ & $13.0 \pm 1.4$ \\
\hline 10 & A 52 US505 & $2.1 \pm 0.1$ & $\leq 0.03$ & $0.76 \pm 0.04$ & $29 \pm 6$ & $\leq 0.0027$ & $0.3 \pm 0.1$ \\
\hline 11 & A 44 US974 & $5.2 \pm 0.3$ & $2.51 \pm 0.10$ & $1.75 \pm 0.07$ & $85 \pm 9$ & $0.0112 \pm 0.0020$ & $\leq 0.10$ \\
\hline 12 & A 24 US404 & $6.7 \pm 0.3$ & $\leq 0.03$ & $6.92 \pm 0.26$ & $135 \pm 13$ & $\leq 0.0039$ & $0.6 \pm 0.1$ \\
\hline 13 & A 47 US 135 & $7.2 \pm 0.4$ & $6.00 \pm 0.2$ & $1.89 \pm 0.09$ & $57 \pm 7$ & $0.0060 \pm 0.0016$ & $\leq 0.10$ \\
\hline 17 & A 52 US675 & $3.2 \pm 0.2$ & $0.17 \pm 0.02$ & $1.46 \pm 0.07$ & $72 \pm 8$ & $0.0130 \pm 0.0025$ & $3.1 \pm 0.4$ \\
\hline
\end{tabular}

between Sardinia and the Aegean. French EB, Wardle KA eds Problems in Greek Prehistory, Bristol Classical Press, Bristol: 349-384. 4 Ludwig KR, Vollmer R, Turi B, Simmons KR, Perna G (1989) Isotopic constraints on the genesis of base-metal ores in Southern and Central Sardinia. European Journal of Mineralogy 1: 657-666. 5 Stos-Gale ZA, Gale NH, Houghton J, Speakman R (1995) Lead isotope data from the Isotrace Laboratory, Oxford: Archaeometry data base 1, ores from the Western Mediterranean. Archaeometry 37: 407415 ZA (1988) Recent evidence for a possible Bronze Age Metal Trade

\begin{tabular}{|c|c|c|c|}
\hline Mineral & ${ }^{207} \mathrm{~Pb} /{ }^{206} \mathrm{~Pb}$ & ${ }^{208} \mathrm{~Pb} /{ }^{206} \mathrm{~Pb}$ & ${ }^{206} \mathrm{~Pb} /{ }^{204} \mathrm{~Pb}$ \\
\hline Galena & 0.87422 & 2.1226 & 17.881 \\
\hline Galena & 0.87420 & 2.1227 & 17.909 \\
\hline Galena & 0.87420 & 2.1234 & 17.901 \\
\hline Galena & 0.87420 & 2.1242 & 17.909 \\
\hline Galena & 0.87419 & 2.1238 & 17.884 \\
\hline Galena & 0.87416 & 2.12074 & 17.850 \\
\hline Galena & 0.87414 & 2.1225 & 17.901 \\
\hline Galena & 0.87411 & 2.1207 & 17.88 \\
\hline Galena & 0.87413 & 2.1230 & 17.871 \\
\hline Galena & 0.87413 & 2.1236 & 17.903 \\
\hline Galena & 0.87409 & 2.1235 & 17.894 \\
\hline Galena & 0.87406 & 2.12025 & 17.869 \\
\hline Galena & 0.87404 & 2.1222 & 17.894 \\
\hline Galena & 0.87403 & 2.1226 & 17.909 \\
\hline Galena & 0.87401 & 2.12304 & 17.903 \\
\hline Galena & 0.87401 & 2.1236 & 17.898 \\
\hline Galena & 0.87398 & 2.1218 & 17.894 \\
\hline Galena & 0.87394 & 2.1226 & 17.896 \\
\hline Galena & 0.87388 & 2.1215 & 17.895 \\
\hline Galena & 0.87387 & 2.1205 & 17.889 \\
\hline Galena & 0.87383 & 2.1244 & 17.897 \\
\hline Galena & 0.87382 & 2.1223 & 17.887 \\
\hline Galena & 0.87377 & 2.11947 & 17.870 \\
\hline Galena & 0.87367 & 2.1187 & 17.867 \\
\hline Galena & 0.87367 & 2.1224 & 17.905 \\
\hline Galena & 0.87357 & 2.11931 & 17.880 \\
\hline Galena & 0.87193 & 2.1201 & 17.951 \\
\hline Galena & 0.87178 & 2.1212 & 17.969 \\
\hline
\end{tabular}


Table 5 Data highlighted from Table 2: 1 Boni M, Koeppel V (1985) Ore-lead isotope pattern from the Iglesiente-Sulcis Area (SW Sardinia) and the problem of remobilization of metals.

Mineralium Deposita 20: 185-193

\begin{tabular}{|c|c|c|c|c|c|}
\hline Biblio & Sample & Sample/mineral & ${ }^{207} \mathrm{~Pb} /{ }^{206} \mathrm{~Pb}$ & ${ }^{208} \mathrm{~Pb} /{ }^{206} \mathrm{~Pb}$ & ${ }^{206} \mathrm{~Pb} /{ }^{204} \mathrm{~Pb}$ \\
\hline & SI_2013_A47_US832 (Sample 1) & Part of weight & 0.87397 & 2.1223 & 17.903 \\
\hline & SI_2010_A24_US51(Sample 2) & Clamp & 0.87389 & 2.1223 & 17.902 \\
\hline & Mining site & & & & \\
\hline 1 & Iglesiente, Buggerru, Pira Roma-S. Luigi & Galena & 0.87382 & 2.1223 & 17.887 \\
\hline 1 & $\begin{array}{l}\text { Iglesiente, San Giovanni Massa Pozzo } 4 \\
\text { (Bindua, Iglesias) }\end{array}$ & Galena & 0.87404 & 2.1222 & 17.894 \\
\hline
\end{tabular}

Table 6 Data from Medoresall database. For Sardinia: 1 Gale NH, Stos-Gale ZA (1987) Oxhide ingots from Sardinia, Crete and Cyprus and the Bronze Age copper trade: new scientific evidence. Studies in Sardinian Archaeology 3. Nuragic Sardinia and the Mycenaean World, BAR IS 387: 159-198. 2 Ludwig KR, Vollmer R, Turi B, Simmons KR, Perna G (1989) Isotopic constraints on the genesis of base-metal ores in Southern and Central Sardinia. European Journal of Mineralogy 1: 657-666. 3 Stos-Gale ZA, Gale NH, Houghton J, Speakman R (1995) Lead isotope data from the Isotrace Laboratory, Oxford: Archaeometry data base 1, ores from the Western Mediterranean. Archaeometry 37: 407-415

\begin{tabular}{|c|c|c|c|c|c|c|c|}
\hline Biblio & Country & Mining District & Mine & Ore & ${ }^{207} \mathrm{~Pb} /{ }^{206} \mathrm{~Pb}$ & ${ }^{208} \mathrm{~Pb} /{ }^{206} \mathrm{~Pb}$ & ${ }^{206} \mathrm{~Pb} /{ }^{204} \mathrm{~Pb}$ \\
\hline 1 & Sardinia, S-W & Arburese & Montevecchio San Antonio (Guspini -Arbus) & Galena & 0.86057 & 2,1073 & 18,203 \\
\hline 2 & Sardinia, S-W & Arburese & Montevecchio Rampa Casargiu (Guspini-Arbus) & Galena & 0.86052 & 2,1090 & 18,211 \\
\hline 3 & Sardinia, S-W & Arburese & Montevecchio Sanna (Guspini-Arbus) & Galena & 0.86028 & 2.10698 & 18.208 \\
\hline 3 & Sardinia, S-W & Arburese & Montevecchio (Guspini-Arbus) & Galena & 0.8602 & 2.10551 & 18.179 \\
\hline 3 & Sardinia, S-W & Arburese & Fenugu Sibiri (Gonnosfanadiga) & Galena & 0.86014 & 2.10412 & 18.224 \\
\hline 3 & Sardinia, S-W & Arburese & Fenugu Sibiri (Gonnosfanadiga) & Galena & 0.86013 & 2.10308 & 18.209 \\
\hline 3 & Sardinia, S-W & Arburese & Monti Mannu (Villacidro) & Galena & 0.86013 & 2.1056 & 18.235 \\
\hline 3 & Sardinia, S-W & Arburese & Montevecchio, Piccalinna (Guspini-Arbus) & Galena & 0.86011 & 2.10539 & 18.170 \\
\hline \multirow[t]{4}{*}{3} & Sardinia, S-W & Arburese & Monti Mannu (Villacidro) & Galena & 0.85978 & 2.10411 & 18.232 \\
\hline & Spain, S-W & Huelva & Minas de Rio Tinto & Galena & 0.86028 & 2.10426 & 18.197 \\
\hline & Spain, S-W & Huelva & Minas de Rio Tinto & Galena & 0.85999 & 2.10356 & 18.186 \\
\hline & Spain, S-W & Huelva & Minas de Rio Tinto & Galena & 0.85983 & 2.10218 & 18.172 \\
\hline
\end{tabular}


Table 7 Data from Medoresall database: 1 Boni M, Koeppel V (1985) Ore-lead isotope pattern from the Iglesiente-Sulcis Area (SW Sardinia) and the problem of remobilization of metals. Mineralium Deposita 20: 185-193. 2 Gale NH, Stos-Gale ZA (1987) Oxhide ingots from Sardinia, Crete and Cyprus and the Bronze Age copper trade: new scientific evidence. Studies in Sardinian Archaeology 3. Nuragic Sardinia and the Mycenaean World, BAR IS 387: 159198. 3 Gale NH, Stos-Gale ZA (1988) Recent evidence for a possible Bronze Age Metal Trade between Sardinia and the Aegean. French EB, Wardle KA eds Problems in Greek Prehistory, Bristol Classical
Press, Bristol: 349-384. 4 Ludwig KR, Vollmer R, Turi B, Simmons KR, Perna G (1989) Isotopic constraints on the genesis of base-metal ores in Southern and Central Sardinia. European Journal of Mineralogy 1: 657-666. 5 Stos-Gale ZA, Gale NH (1992) New light on the provenience of the copper oxhide ingots found on Sardinia. Tykot RH, Andrews TK eds, Sardinia in the Mediterranean: A Footprint in the Sea, Sheffield Academic Press, Sheffield: 317-345. 6 Stos-Gale ZA, Gale NH, Houghton J, Speakman R (1995) Lead isotope data from the Isotrace Laboratory, Oxford: Archaeometry data base 1, ores from the Western Mediterranean. Archaeometry 37: 407-415

\begin{tabular}{|c|c|c|c|c|c|c|c|}
\hline Biblio & Country & Mining district & Mine & Ore & ${ }^{207} \mathrm{~Pb} /{ }^{206} \mathrm{~Pb}$ & ${ }^{208} \mathrm{~Pb} /{ }^{206} \mathrm{~Pb}$ & ${ }^{206} \mathrm{~Pb} /{ }^{204} \mathrm{~Pb}$ \\
\hline 1 & Sardinia, S-W & Sulcis & Rosas-Sa Marchesa (Nuxis, SU) & Galena & 0.85826 & 2.1023 & 18.252 \\
\hline 6 & Sardinia, S-W & Sulcis & Sa Marchesa (Nuxis, SU) & Galena, sphalerite & 0.85822 & 2.10101 & 18.221 \\
\hline 6 & Sardinia, S-W & Sulcis & Rosas, (Nuxis, SU) & Galena, malachite & 0.85814 & 2.10272 & 18.283 \\
\hline 6 & Sardinia, S-W & Sulcis & Rosas, (Nuxis, SU) & Galena, malachite & 0.85801 & 2.10182 & 18.277 \\
\hline $2-3-5$ & Sardinia, S-W & Sulcis & Rosas, (Narcao, SU) & Galena & 0.85799 & 2.1024 & 18.259 \\
\hline 6 & Sardinia, S-W & Sulcis & Sa Marchesa (Nuxis, SU) & Galena, sphalerite & 0.85779 & 2.09738 & 18.220 \\
\hline 6 & Sardinia, S-W & Sulcis & Rosas, (Nuxis, SU) & Galena, malachite & 0.85769 & 2.10075 & 18.245 \\
\hline 6 & Sardinia, S-W & Sulcis & Rosas, (Nuxis, SU) & Galena, malachite & 0.85769 & 2.09963 & 18.247 \\
\hline 6 & Sardinia, S-W & Sulcis & Truba Niedda (Nuxis, SU) & Galena, sphalerite, pyrite & 0.85767 & 2.10014 & 18.250 \\
\hline 5 & Sardinia, S-W & Sulcis & Truba Niedda (Nuxis, SU) & Galena & 0.85742 & 2.09804 & 18.232 \\
\hline 6 & Sardinia, S-W & Sulcis & Rosas, (Nuxis, SU) & Galena, malachite & 0.85740 & 2.09914 & 18.246 \\
\hline 3 & Sardinia, S-W & Sulcis & Monte Tamara & Galena; sphalerite & 0.85739 & 2.10256 & 18.357 \\
\hline 5 & Sardinia, S-W & Sulcis & Rosas, (Nuxis, SU) & Galena, malachite & 0.85738 & 2.09861 & 18.237 \\
\hline 6 & Sardinia, S-W & Sulcis & Truba Niedda (Nuxis, SU) & Galena, sphalerite, pyrite, & 0.85724 & 2.09804 & 18.232 \\
\hline 1 & Sardinia, S-W & Sulcis & Narcao, M. Atzei-S. Croce & Galena & 0.85715 & 2.1001 & 18.257 \\
\hline $2-3-5$ & Sardinia, S-W & Sulcis & Sa Marchesa (Nuxis, SU) & Galena & 0.85698 & 2.09737 & 18.290 \\
\hline 4 & Sardinia, S-W & Sulcis & Mont'Ega (Narcao) & Galena & 0.85627 & 2.1020 & 18.298 \\
\hline
\end{tabular}

Table 8 Data from Medoresall database: 1 Gale NH, Stos-Gale ZA (1987) Oxhide ingots from Sardinia, Crete and Cyprus and the Bronze Age copper trade: new scientific evidence. Studies in Sardinian Archaeology 3. Nuragic Sardinia and the Mycenaean World, BAR IS 387: 159-198. 2 Gale NH, Stos-Gale ZA (1988) Recent evidence for a possible Bronze Age Metal Trade between Sardinia and the Aegean. French EB, Wardle KA eds Problems in Greek Prehistory, Bristol Classical Press, Bristol: 349-384. 3 Stos-Gale ZA, Gale
NH (1992) New light on the provenience of the copper oxhide ingots found on Sardinia. Tykot RH, Andrews TK eds, Sardinia in the Mediterranean: A Footprint in the Sea, Sheffield Academic Press, Sheffield: 317-345. 4 Stos-Gale ZA, Gale NH, Houghton J, Speakman R (1995) Lead isotope data from the Isotrace Laboratory, Oxford: Archaeometry data base 1, ores from the Western Mediterranean. Archaeometry 37: 407-415

\begin{tabular}{lllllll}
\hline Biblio & Country & Mining district & Mine & Ore & ${ }^{207} \mathrm{~Pb} /{ }^{206} \mathrm{~Pb}$ & ${ }^{208} \mathrm{~Pb} /{ }^{206} \mathrm{~Pb}$ \\
\hline $1-2$ & Sardinia, N-W & Sassarese & Argentiera, Nurra & Tetrahedrite & 0.85758 & 2.10624 \\
$1-2$ & Sardinia, N-W & Sassarese & Argentiera, Nurra & Galena & 0.85667 & 2.10683 \\
$1-2$ & Sardinia, N-W & Sassarese & Argentiera, Nurra & Galena & 0.85609 & 2.10564 \\
3 & Sardinia, S-E & Sarrabus-Gerrei & Pranu e'Sanguini & Galena, sphalerite & 0.85813 & 2.10498 \\
3 & Sardinia, S-E & Sarrabus-Gerrei & Pranu e'Sanguini & Galena, sphalerite & 0.85637 & 2.10156 \\
4 & Sardinia, S-E & Sarrabus-Gerrei & Pranu e'Sanguini & Galena, sphalerite & 0.85635 & 2.10156 \\
3 & Sardinia, S-E & Sarrabus-Gerrei & Pranu e'Sanguini & Galena & 0.85635 & 2.10156 \\
4 & Sardinia, S-E & Sarrabus-Gerrei & Pranu e'Sanguini & Galena, sphalerite & 0.85622 & 2.10099 \\
4 & Sardinia, S-E & Sarrabus-Gerrei & Pranu e'Sanguini & Galena, sphalerite & 0.85619 & 2.10007 \\
4 & Sardinia, S-E & Sarrabus-Gerrei & Pranu e'Sanguini & Galena, sphalerite & 0.85611 & 2.10012 \\
4 & Sardinia, S-E & Sarrabus-Gerrei & Pranu e'Sanguini & Galena, sphalerite & 0.85582 & 18.321 \\
\hline
\end{tabular}


Table 9 Montero-Ruiz, I (2017) La Solana del Bepo from an archaeometallurgical perspective. Rafel, N., Soriano, I. Delgado-Raack, S (edd) A prehistoric copper mine in the Noth-East of the Iberian Peninsula: Solana del Bepo (Uldemolins, Tarragona). Revista de Arqueologia de Ponet, extra 2: 65-79

\begin{tabular}{lllllll}
\hline Country & Mining district & Mine & Ore & ${ }^{207} \mathrm{~Pb} /{ }^{206} \mathrm{~Pb}$ & ${ }^{208} \mathrm{~Pb} /{ }^{206} \mathrm{~Pb}$ & ${ }^{206} \mathrm{~Pb} /{ }^{204} \mathrm{~Pb}$ \\
\hline Spain & Catalan Coastal Ranges & Barranco Hondo & Galena & 0.85646 & 2.1024 & 18.310 \\
Spain & Catalan Coastal Ranges & Mineralogia & Galena & 0.85638 & 2.1029 & 18.318 \\
Spain & Catalan Coastal Ranges & Jalapa & Galena & 0.85631 & 2.1021 & 18.311 \\
Spain & Catalan Coastal Ranges & Mina Regia & Galena & 0.85631 & 2.1015 & 18.301 \\
Spain & Catalan Coastal Ranges & Linda Mariquita & Galena & 0.85624 & 2.1026 & 18.322 \\
Spain & Catalan Coastal Ranges & Mineralogia & Galena & 0.85624 & 2.1019 & 18.309 \\
Spain & Catalan Coastal Ranges & Cueva del Paraguas & Galena & 0.85616 & 2.1011 & 18.299 \\
Spain & Catalan Coastal Ranges & Linda Mariquita & Galena & 0.85609 & 2.1019 & 18.316 \\
Spain & Catalan Coastal Ranges & Mineralogia & Galena & 0.85609 & 2.1011 & 18.301 \\
Spain & Catalan Coastal Ranges & Barranco Hondo & Galena & 0.85609 & 2.1017 & 18.313 \\
Spain & Catalan Coastal Ranges & Raimunda & Galena & 0.85594 & 2.1024 & 18.333 \\
Spain & Catalan Coastal Ranges & Raimunda & Galena & 0.85587 & 2.1024 & 18.333 \\
Spain & Catalan Coastal Ranges & Barranco Hondo & Galena & 0.85580 & 2.1004 & 18.301 \\
Spain & Catalan Coastal Ranges & Linda Mariquita & Galena & 0.85572 & 2.1013 & 18.323 \\
Spain & Catalan Coastal Ranges & Linda Mariquita & Galena & 0.85565 & 2.1011 & 18.322 \\
Spain & Catalan Coastal Ranges & Raimunda & Galena & 0.85565 & 2.1010 & 18.317 \\
Spain & Catalan Coastal Ranges & Linda Mariquita & Galena & 0.85536 & 2.0999 & 18.308 \\
Spain & Catalan Coastal Ranges & Linda Mariquita & Galena & 0.85521 & 2.0994 & 18.316 \\
Spain & Catalan Coastal Ranges & Linda Mariquita & Galena & 0.85514 & 2.1027 & 18.353 \\
Spain & Catalan Coastal Ranges & Linda Mariquita & Galena & 0.85477 & 2.0996 & 18.338 \\
\hline & & & & & &
\end{tabular}

Table 10 New data from LIMS

\begin{tabular}{llllllc}
\hline Country & Mining District & Mine & Ore & ${ }^{207} \mathrm{~Pb} /{ }^{206} \mathrm{~Pb}$ & ${ }^{208} \mathrm{~Pb} /{ }^{206} \mathrm{~Pb}$ & ${ }^{206} \mathrm{~Pb} /{ }^{204} \mathrm{~Pb}$ \\
\hline Spain & Sierra Morena & Azuaga-Fuenteovejuna & Galena & 0.85800 & 2.1061 & 18.206 \\
Spain & Sierra Morena & Azuaga-Fuenteovejuna & Galena & 0.85785 & 2.1089 & 18.194 \\
Spain & Sierra Morena & Linares (La Carolina) & Galena & 0.85778 & 2.1058 & 18.188 \\
\hline
\end{tabular}

Table 11 Data from Medoresall database: 1 Gale NH, Stos-Gale ZA (1987) Oxhide ingots from Sardinia, Crete and Cyprus and the Bronze Age copper trade: new scientific evidence. Studies in Sardinian Archaeology 3. Nuragic Sardinia and the Mycenaean World, BAR IS 387: 159-198. 2 Gale NH, Stos-Gale ZA (1988) Recent evidence for a possible Bronze Age Metal Trade between Sardinia and the Aegean. French EB, Wardle KA eds Problems in Greek Prehistory, Bristol Classical Press, Bristol: 349-384. 3 Stos-Gale ZA, Gale
NH (1992) New light on the provenience of the copper oxhide ingots found on Sardinia. Tykot RH, Andrews TK eds, Sardinia in the Mediterranean: A Footprint in the Sea, Sheffield Academic Press, Sheffield: 317-345. 4 Stos-Gale ZA, Gale NH, Houghton J, Speakman $\mathrm{R}$ (1995) Lead isotope data from the Isotrace Laboratory, Oxford: Archaeometry data base 1, ores from the Western Mediterranean. Archaeometry 37: 407-415

\begin{tabular}{|c|c|c|c|c|c|c|c|}
\hline Biblio & Country & Mining district & Mine & Ore & ${ }^{207} \mathrm{~Pb} /{ }^{206} \mathrm{~Pb}$ & ${ }^{208} \mathrm{~Pb} /{ }^{206} \mathrm{~Pb}$ & ${ }^{206} \mathrm{~Pb} /{ }^{204} \mathrm{~Pb}$ \\
\hline 4 & Central Sardinia & Barbagia & Funtana Raminosa & Galena, sphalerite & 0.85773 & 2.09861 & 18.212 \\
\hline 4 & Central Sardinia & Barbagia & $\begin{array}{l}\text { Funtana Raminosa (Gal. } \\
\text { Yvonne no. 3) }\end{array}$ & Galena (silver), sphalerite & 0.85737 & 2.09758 & 18.197 \\
\hline $1-2-3$ & Central Sardinia & Barbagia & Funtana Raminosa & Galena & 0.85694 & 2.09758 & 18.197 \\
\hline 4 & Central Sardinia & Barbagia & Funtana Raminosa & Galena (silver), sphalerite & 0.85676 & 2.09895 & 18.254 \\
\hline 4 & Central Sardinia & Barbagia & Funtana Raminosa & Galena, chalcopyrite & 0.85599 & 2.09502 & 18.203 \\
\hline $1-2$ & Central Sardinia & Barbagia & Funtana Raminosa & Galena; sphalerite & 0.85448 & 2.09413 & 18.293 \\
\hline
\end{tabular}


Table 12 Montero-Ruiz, I (2017) La Solana del Bepo from an archaeometallurgical perspective. Rafel, N., Soriano, I. DelgadoRaack, S (edd) A prehistoric copper mine in the Noth-East of the Ibe- rian Peninsula: Solana del Bepo (Uldemolins, Tarragona). Revista de Arqueologia de Ponet, extra 2: 65-79; Sardinia: Oxalid Italy, Sample, Sard 49A

\begin{tabular}{|c|c|c|c|c|c|c|c|}
\hline \multirow{2}{*}{$\begin{array}{l}\text { Country } \\
\text { Spain }\end{array}$} & \multicolumn{2}{|l|}{ Mining district } & \multirow{2}{*}{$\begin{array}{l}\text { Ore } \\
\text { Galena }\end{array}$} & \multirow{2}{*}{$\begin{array}{l}\text { Mine } \\
\text { Linda Mariquita }\end{array}$} & \multirow{2}{*}{$\begin{array}{l}{ }^{207} \mathrm{~Pb} /{ }^{206} \mathrm{~Pb} \\
0.85448\end{array}$} & \multirow{2}{*}{$\begin{array}{l}{ }^{208} \mathrm{~Pb} /{ }^{206} \mathrm{~Pb} \\
2.1003\end{array}$} & \multirow{2}{*}{$\begin{array}{l}{ }^{206} \mathrm{~Pb} /{ }^{204} \mathrm{~Pb} \\
18.357\end{array}$} \\
\hline & Catalan Coastal Ranges & MBF & & & & & \\
\hline Spain & Catalan Coastal Ranges & Montsant & Galena & Mina Besso & 0.85412 & 2.0970 & 18.352 \\
\hline Spain & Catalan Coastal Ranges & $\mathrm{MBF}$ & Galena & Balcoll & 0.85404 & 2.0986 & 18.358 \\
\hline Spain & Catalan Coastal Ranges & $\mathrm{MBF}$ & Silver & Balcoll & 0.85353 & 2.0971 & 18.358 \\
\hline Italy & Sardinia & Barbagia & Galena & Funtana Raminosa & 0.85455 & 2.0924 & 18.293 \\
\hline Spain & Sierra Morena & Pedroches & Galena & La Atalaya (CO 12) Alcaracejos & 0.85448 & 2.1015 & 18.262 \\
\hline Spain & Sierra Morena & Pedroches & Galena & Miniera El Soldado (CO 109) & 0.85383 & 2.1007 & 18.327 \\
\hline Spain & South-East & Sierra de Alhamilla & Galena & Pantano Nìjar & 0.85463 & 2.1006 & 18.327 \\
\hline Spain & South-East & Sierra de Alhamilla & Galena & Coto Laisquez & 0.85463 & 2.1005 & 18.323 \\
\hline Spain & South-East & Sierra de Alhamilla & Galena & Coto Laisquez & 0.85463 & 2.1005 & 18.321 \\
\hline Spain & South-East & Sierra de Gador & Galena & Tolva & 0.85455 & 2.1030 & 18.339 \\
\hline Spain & South-East & Cartagena & Galena & Sierra de Cartagena, Filone San Juliàn & 0.85412 & 2.0998 & 18.321 \\
\hline Spain & South-West & Huelva & $\mathrm{Pb}$ & Rio Tinto (H43), Cueva del Lago & 0.85455 & 2.1022 & 18.348 \\
\hline
\end{tabular}

Table 13 Antolinos Marin JA, Domergue C, Manteca JI, Palero Fernández FJ, Quarati P, Rico C, Stefanile M, Trincherini PR (in press) Lateres Plumbei Hispani. Production et commerce du plomb hispanique à l'époque romaine (II ${ }^{\mathrm{e}}$ s. av. J.-C. - II ${ }^{\mathrm{e}}$ s. ap. J.-C.), Ed. Casa de Velásquez, Madrid. (accepted November 2020); Arribas and Tosdal 1994

\begin{tabular}{|c|c|c|c|c|c|c|c|}
\hline \multirow{2}{*}{$\begin{array}{l}\text { Spain } \\
\text { Central-East }\end{array}$} & \multicolumn{2}{|l|}{ Mining district } & \multirow{2}{*}{$\begin{array}{l}\text { Ore } \\
\text { Galena }\end{array}$} & \multirow{2}{*}{$\begin{array}{l}\text { Mine } \\
\text { Torre de la Sal }\end{array}$} & \multirow{2}{*}{$\begin{array}{l}{ }^{206} \mathrm{~Pb} /{ }^{207} \mathrm{~Pb} \\
0.84069\end{array}$} & \multirow{2}{*}{$\begin{array}{l}{ }^{208} \mathrm{~Pb} /{ }^{206} \mathrm{~Pb} \\
2.0838\end{array}$} & \multirow{2}{*}{$\begin{array}{l}{ }^{206} \mathrm{~Pb} /{ }^{204} \mathrm{~Pb} \\
18.657\end{array}$} \\
\hline & Castellón & Plana Alta & & & & & \\
\hline Central-East & Castellón & Plana Alta & Lead & Torre de la Sal & 0.83780 & 2.0841 & 18.731 \\
\hline Central-East & Castellón & Plana Alta & Lead & Torre de la Sal & 0.83710 & 2.0835 & 18.747 \\
\hline Sierra Morena & Azuaga-Fuenteovejuna & Fuenteovejuna & Lead & La Loba (CO 55), Village & 0.83773 & 2.0840 & 18.709 \\
\hline South-East & Cartagena-Mazarrón & Cartagena & Scoria & La Balsa & 0.83963 & 2.0886 & 18.768 \\
\hline South-East & Cartagena-Mazarrón & Cartagena & Galena & S.Valentin & 0.83949 & 2.0877 & 18.774 \\
\hline South-East & Cartagena-Mazarrón & Cartagena & Galena & Navidad & 0.83759 & 2.0837 & 18.722 \\
\hline South-East & Cartagena-Mazarrón & Cartagena & Galena & Cabezo Rajado & 0.83752 & 2.0840 & 18.739 \\
\hline South-East & Cartagena-Mazarrón & Cartagena & Galena (manto) & Cartagena (MU3) & 0.83731 & 2.0832 & 18.707 \\
\hline South-East & Cartagena-Mazarrón & Mazarrón & Galena & San Cristobal & 0.83710 & 2.0842 & 18.765 \\
\hline South-East & Cartagena-Mazarrón & Cartagena & Scoria & $\begin{array}{l}\text { Cala Reona Sierra de Carta- } \\
\text { gena }\end{array}$ & 0.83605 & 2.0832 & 18.693 \\
\hline South-West & Huelva & $\begin{array}{c}\text { Cinture pyriteuse } \\
\text { du Sud-Ouest }\end{array}$ & Lead $\left(n^{\circ} 21.67\right)$ & Cueva del Lago (Rio Tinto) & 0.83752 & 2.0839 & 18.728 \\
\hline
\end{tabular}

Acknowledgements We thank two anonymous reviewers and the Editor Elisabetta Gliozzo who provided criticism that improved our argumentation. We would also like to thank M.E. Minoja, M. Picciau, F. di Gennaro, Soprintendenti of the SABAP Sassari e Nuoro for the suggestions and the help given in these years of work; M. Pearce for fruitful exchanges of ideas and for many suggestions. D. Brett has read the work and made useful corrections; V. Romanò for the excellent work during her master's degree thesis.

Author contribution M.Ca. and E.F. coordinated the scientific project, organized the different parts of the team, and gave important criticisms and advices; I.M.V., P.R.T, M.Cl., S.N., M.F., V.S., and P.O. were part of the two teams, LNGS and Università di Milano Bicocca, who made the measures and produced the text; B.B., G.G., and M.R. constituted the archaeological part of the team, both of the Soprintendenza Archeologia, Belle Arti e Paesaggio per le province di Sassari e Nuoro, and Università di Sassari, which have the co-direction of the archaeological project.

Funding Open access funding provided by Università degli Studi di Sassari within the CRUI-CARE Agreement. This work is funded by the University of Sassari (Italy), "Fondo di Ateneo per la ricerca 2019", by the project funded in 2017 by Fondazione Sardegna "Vita quotidiana e trasformazioni in due siti costieri del nord Sardegna", and by INFN Cultural Heritage Network (CHNet).

Open Access This article is licensed under a Creative Commons Attribution 4.0 International License, which permits use, sharing, adaptation, distribution and reproduction in any medium or format, as long as you give appropriate credit to the original author(s) and the source, provide a link to the Creative Commons licence, and indicate if changes were made. The images or other third party material in this article are 
included in the article's Creative Commons licence, unless indicated otherwise in a credit line to the material. If material is not included in the article's Creative Commons licence and your intended use is not permitted by statutory regulation or exceeds the permitted use, you will need to obtain permission directly from the copyright holder. To view a copy of this licence, visit http://creativecommons.org/licenses/by/4.0/.

\section{References}

Aguayo De Hoyos P (2018) La problematica de la trasmision tecnologica: el caso de la metalurgia protohistorica en el extremo Occidente mediterraneo. Implicaciones desde el registro arqueologico de algunos asentamientos del interior de los sistemas beticos (Andalucia, Espana). Pholia Phoenicia 2:231-235

Alberti, M. E., Ascalone, E., Parise, N., Peyronel, L. (2006). Weights in context. Current approaches to the study of the ancient weight systems. M. E. Alberti, E. Ascalone, L. Peyronel (edd), Weights in context. Bronze Age weighing systems of Eastern Mediterranean. Chronology, typology, material and archaeological context, Proceedings of the international colloquium, Rome 22th- $24^{\text {th }}$ November 2004. Studi e Materiali 13:1-8

Arribas A, Tosdal RM (1994) Isotopic composition of $\mathrm{Pb}$ in ore deposits of the Betic Cordillera, Spain: origin and relationship to other European Deposits. Econ Geol 89:1074-1093

Atzeni, C., Massidda, L., Sanna, U. (2005) Investigations and results. N. Lead, F. Lo Schiavo, A. Giumlia-Mair, U. Sanna, R. Valera (edd), Archaeometallurgy in Sardinia from the origins to the beginning of the Early Iron Age. Montagnac: Editions Monique Mergoil, pp 160-172

Aubet, M. E. (2002). Nota sobre tres pesos fenicios del Cerro del Villar (Málaga). Amadasi Guzzo MG, Liverani M, Matthiae P (edd) Da Pyrgy a Mozia. Studi sull'archeologia del Mediterraneo in memoria di Antonia Ciasca. Roma pp 29-40

Bafico, S. (1998). Nuraghe e villaggio Sant'Imbenia, Alghero. Betagamma, Viterbo

Bafico, S., D’Oriano, R., Lo Schiavo, F. (1985). Il villaggio nuragico di Sant'Imbenia (SS). Nota preliminare. Actes du IIIe Congres International des Études phéniciennes et puniques, Tunis, pp 87-94.

Balassone, G., Boni, M., Di Maio, G., Fariello, M., Villa, I. M. (2002). Analysis of the rings found in the Samnitic necropolis of Saticula (Sant'Agata dei Goti, Benevento, Italy). E. Jerem, K. T. Biró (edd) Proceedings, $31^{\text {st }}$ Symposium on Archeometry, Oxford: Archeopress, pp 279-283

Begemann F, Schmitt-Strecker S, Pernicka E, Lo Schiavo F (2001) Chemical composition and lead isotopy of copper and bronze from Nuragic Sardinia. Eur J Archaeol 4(1):43-85

Casi C (2018) Etruschi in Trasferta. Archeo 397:6-8

Craddock, P. T., Freestone, I. C., Gale, N. H., Meeks, N. D., Rothenberg, B., Tite, N. S. (1985). The investigation of a small heap of silver smelting debris fro Rio Tinto, Huelva, Spain. P. T. Craddock, M. J. Hughes (edd), Furnaces and smelting technology in antiquity, Occasional Paper No. 48, London: British Museum, pp 199-217.

Depalmas, A., Fundoni, G., Luongo, F. (2011). Ripostiglio di bronzi della prima età del ferro a Sant'Imbenia - Alghero (Sassari). Rivista di Scienze Preistoriche LXI:231-256.

De Rosa B (2017) Percorsi ceramici. Analisi archeometriche e tecnologiche sulle ceramiche di Sant'Imbenia. Officina Etruscologia 14, Roma: Officina Edizioni

De Rosa B, Garau E (2016) The Sant'Imbenia amphorae. Proceedings of IMEKO, International Conference on Metrology for Archaeology and Cultural Heritage (Torino, Italy, October 19-21 2016). Turin, pp 230-234
De Rosa B, Garau E, Rendeli M, Sanna L (2017) Sant'Imbenia. Moravetti A, Melis P, Foddai L, Alba E (edd) La Sardegna nuragica. Storia e monumenti (=Corpora delle antichità della Sardegna), Sassari, pp 115-145.

De Rosa B, Garau E, Rendeli M (2018) Interaction by design: relation between Carthage and North Western Sardinia. Byrsa, Scritti Sull'antico Oriente Mediterraneo 33-34:49-78

di Gennaro F (2019) Uno stanziamento "etrusco" del X secolo a.C. a Tavolara. Rafanelli S, La Battaglia che ha cambiato la storia, Alalía. Etruschi, Greci e Cartaginesi nel Mediterraneo del VI secolo a.C., Ara Edizioni, Siena, pp 54-57

Domergue C, Rico C, Antolinos Marin JA, Manteca JI, Palero Fernández FJ, Quarati P, Stefanile M, Trincherini PR in press. Lateres Plumbei Hispani. Production et commerce du plomb hispanique à l'époque romaine (II ${ }^{\mathrm{e}} \mathrm{s}$. av. J.-C. - II ${ }^{\mathrm{e}}$ s. ap. J.-C.)

Gale NH (2006) 2/ Lead Isotope Studies. Sardinia and the Mediterranean Provenance Studies of artefacts found in Sardinia. Archaeometallurgy in Sardinia: from the Origin to the early Iron Age, the $10^{\text {th }}$ and $11^{\text {th }}$ September 2004. Instrumentum 23:29-34

Gale NH, Stos Gale Z (1987) Oxhide ingots from Sardinia, Crete and Cyprus and the Bronze Age copper trade: new scientific evidence. Studies in Sardinian Archaeology 3. Nuragic Sardinia and the Mycenaean World, BAR IS 387, pp 159-198

Gale NH, Stos Gale Z (1988) Recent evidence for a possible Bronze Age Metal Trade between Sardinia and the Aegean. French EB, Wardle KA (edd) Problems in Greek Prehistory, Bristol: Bristol Classical Press, pp 349-384

Gale NH, Stos-Gale Z, Houghton J, Speakman R (1997) Lead Isotope Isotrace Laboratory, Oxford. Archaeometry data base 4, ores from Cyprus. Archaeometry 39:237-246

Gale NH, Giardino C, Parise Presicce C (2005) La provenienza del metallo adoperato nella fabbricazione della Lupa Capitolina. Studi Etruschi 71:129-141

Giardino C (1992) Nuragic Sardinia and the Mediterranean: metallurgy and maritime traffic. Tykot RH, Andrews TK (edd) Sardinia in the Mediterranean: a footprint in the sea. Studies in Sardinian Archaeology, Presented to Miriam S. Balmuth. Sheffield: Sheffield Academic Press, pp 304-316

Giardino C (2010) I metalli nel mondo antico. Introduzione all' archeometallurgia. Editori Laterza, Roma-Bari

Giardino C, Lo Schiavo F (2007) Ripostigli sardi algheresi della tarda età nuragica. Nuove ricerche archeometallurgiche. Roma: Bagatto Libri

Giardino C, Pinarelli (2007) Indagini sulla composizione isotopica del $\mathrm{Pb}$ nei lingotti dei ripostigli di S. Imbenia. Giardino $\mathrm{C}$ and Lo Schiavo $\mathrm{F}$ (edd) I ripostigli algheresi della tarda età nuragica. Nuove ricerche archeometallurgiche, Bagatto Libri, Roma, pp 21-31

Grögler N, Geiss J, Grünenfelder M, Houtermans FC (1966) Isotopenuntersuchungen zur Bestimmung der Herkunft römischer Bleirohre und Bleibarren. Z Naturforsch 21:1167-1172

Hernández CM (2018) Trans-Mediterranean silver-trade from the perspective of Iberian ores and Hacksilber in the Cisjordan Corpus. Pholia Phoenicia 2:87-91

Kang J, Wille M, Hofmann BA, Strauss H, Villa IM (2020) Heterogeneous lead isotopic compositions of sulfide minerals from a hydrothermal replacement deposit (Janggun mine, South Korea). Ore Geol Rev 122(103527):1-23

Lo Schiavo F (2006) Western weights in context, in Alberti ME, Ascalone E, Peyronel L (edd) Weights in context. Bronze Age weighing systems of Eastern Mediterranean. Chronology, typology, material and archaeological context. Proceedings of the international colloquium, Rome 22 th- $24^{\text {th }}$ November 2004. Studi e Materiali 13:1-8

Marino T (2014) Sant'Imbenia (Alghero-SS): prime considerazioni sull'ambiente 48 e sul ripostiglio dei semi di cardo. Neri S (ed) 
Tecniche di conservazione e forme di stoccaggio in area tirrenica e Sardegna. Roma: Officina Etruscologia, pp 49-58

Pearce M (2018) The 'island of silver veins': an overview of the earliest metal and metalworking in Sardinia. Metalla 23(2):91-111

Perelló L, Llull B (2019) Circulación y consumo de plomo en las Islas Baleares durante la edad del hierro. Nuevos datos isotópicos de galenas y metales arqueológicos. Zephyrus 84:89-113

Rendeli M (2018) Sant'Imbenia and the Topic of the Emporia in Sardinia. Gailledrat E, Dietler M, Plana-Mallart R (edd) The Emporion in the Ancient Western Mediterranean. Trade and Colonial Encounters from the Archaic to the Hellenistic Period. Montpellier: Presses Universitaires de la Méditerranee, pp 191-204.

Renzi M, Rovira Llorens S (2015) Las metalurgias fenicias en el Mediterráneo. Phicaria. III encuentros internacioanales del Mediterráneo. Minería y metalurgia en el Mediterráneo y su periferia oceánica, I.G. Novoarte S.L., Murcia, pp 113-128

Renzi M, Montero-Ruiz I, Bode M (2009) Non-ferrous metallurgy from the Phoenician site of La Fonteta (Spain): a study of provenance. J Archaeol Sci 36:2584-2596

Renzi M, Rovira Llorens S, Montero Ruiz I (2012) Riflessioni sulla metallurgia fenicia dell' argento nella Penisola Iberica. Notizie Archeologiche Bergomensi 20:185-194

Romanò V (2016) Sviluppo di metodiche analitiche per l'analisi elementare di campioni archeologici mediante attivazione neitronica. Università degli Studi di Milano-Bicocca Scuola di Scienze - Corso di Laurea Magistrale in Scienze e Tecnologie Chimiche - Anno Accademico 2015/2016 http://www.infn.it/thesis/PDF/ getfile.php?filename $=11887$--specialistica.pdf

Rovira S and Renzi M (2013) Plata tartésica: una revisión de la tecnología extractiva a la luz de nuevos hallazgos. Campos JM, Alvar J (edd) Tarteso. El emporio del metal, Almuzara Editorial, Cordoba, pp 473-488

Ruiz-Gálvez M (2003) Investigating weight system in Nuragic Sardinia. Giumlia-Mair A and Lo Schiavo F (edd) Le probléme de l'étain à l'origine de la métallurgie: The problem of Early Tin. BAR Int. Series 1199, Oxford, pp 147-157

Stos Gale S, Gale NH, Houghton J, Speakman R (1995) Lead isotope data from the Isotrace laboratory, Oxford: Archaeometry data base 1, ores from the Western Mediterranean. Archaeometry 37(2):407-415

Trincherini PR, Contini S, Perucchini L (1983) Finnigan Mat Application Note, n. 49

Trincherini PR, Barbero P, Quarati P, Domergue C, Long L (2001) Where do the lead ingots of the Saintes-maries-de-la-mer wreck come from? Archaeology Compared with Physics. Archaeometry 43:393-406

Trincherini PR, Domergue C, Manteca I, Nesta A, Quarati P (2009) The identification of lead ingots from the Roman mines of Cartagena: the rôle of lead isotope analysis. J Roman Archaeol 22:123-145

Ugas G (1993) La metallurgia del piombo, dell'argento e dell'oro nella Sardegna prenuragica e nuragica. Kirova T (ed) L'uomo e le miniere in Sardegna. Cagliari: Edizione della Torre, pp 25-35

Valera PG and Valera RG (2005) Outline of geology and mineral deposits of Sardinia. Lo Schiavo F, Giumlia-Mair A, Sanna U, Valera R (edd) Archaeometallurgy in Sardinia from the origins to the beginning of the Early Iron Age. Montagnac: Editions Monique Mergoil, pp 35-42

Valera RG, Valera PG, Rivoldini A (2005) Sardinian ore deposits and metals in the Bronze Age. Lo Schiavo F, Giumlia-Mair A, Sanna U, Valera R (edd) Archaeometallurgy in Sardinia from the origins to the beginning of the Early Iron Age. Montagnac: Editions Monique Mergoil, pp 43-88.

Villa IM (2009) Lead isotopic measurements in archeological objects. Archaeol Anthropol Sci 1:149-153

Villa IM (2016) Provenancing Bronze: exclusion, inclusion, uniqueness, and Occam's Razor. Grupe G and McGlynn G (edd) Isotopic Landscapes in Bioarchaeology. Berlin, Heidelberg: Springer, pp $141-154$

Villa IM, Giardino C (2019) Analisi isotopiche del piombo su reperti bronzei di Frattesina. Bietti Sestieri AM, Bellintani P, Giardino C (edd) Frattesina: un centro internazionale di produzione e di scambio nella tarda età del bronzo del Veneto. Roma: Accademia dei Lincei, pp. 255-261

Zaccagnini C (1991) "Nuragic" Sardinia: metrological notes. Atti II Congresso Internazionale di Studi Fenici e Punici. Consiglio Nazionale delle Ricerche, Roma, pp 343-347

Zifferero A (1998) Attività estrattive e metallurgiche nell'area tirrenica. Alcune osservazioni sui rapporti tra Etruria e Sardegna. Etruria e Sardegna centro settentrionale tra l'età del bronzo finale e l'arcaismo, in Atti del XXI Convegno di Studi Etruschi ed Italici. Sassari-Alghero-Torralba, pp 179-212.

Publisher's note Springer Nature remains neutral with regard to jurisdictional claims in published maps and institutional affiliations. 